\title{
Investor attention and idiosyncratic risk in cryptocurrency markets
}

\section{Shouyu Yao, Xiaoran Kong, Ahmet Sensoy, Erdinc Akyildirim \& Feiyang} Cheng

To cite this article: Shouyu Yao, Xiaoran Kong, Ahmet Sensoy, Erdinc Akyildirim \& Feiyang Cheng (2021): Investor attention and idiosyncratic risk in cryptocurrency markets, The European Journal of Finance, DOI: 10.1080/1351847X.2021.1989008

To link to this article: https://doi.org/10.1080/1351847X.2021.1989008

册 Published online: 18 Dec 2021.

Submit your article to this journal $\pi$

Џll Article views: 105

Q View related articles $\asymp$

View Crossmark data $־$ 


\title{
Investor attention and idiosyncratic risk in cryptocurrency markets
}

\author{
Shouyu Yao ${ }^{\mathrm{a}, \mathrm{b}}$, Xiaoran Kong ${ }^{\mathrm{c}}$, Ahmet Sensoy (1) d, Erdinc Akyildirim ${ }^{\mathrm{e}, \mathrm{f}}$ and Feiyang Cheng (D),b \\ ${ }^{a}$ College of Management and Economics, Tianjin University, Tianjin, People's Republic of China; ${ }^{b}$ Macquarie Business School, \\ Macquarie University, Sydney, Australia; 'School of Finance, Shandong University of Finance and Economics, Jinan, People's \\ Republic of China; ${ }^{\mathrm{d}}$ Faculty of Business Administration, Bilkent University, Ankara, Turkey; ${ }^{\mathrm{e}}$ Department of Banking and Finance, \\ University of Zurich, Zurich, Switzerland; ${ }^{f}$ Department of Banking and Finance, Burdur Mehmet Akif Ersoy University, Burdur, \\ Turkey
}

\begin{abstract}
We explore the impact of investor attention on idiosyncratic risk in the cryptocurrency markets. Taking the Google Trends Index as the measure of investor attention, we find that investor attention can significantly reduce cryptocurrencies' idiosyncratic risks by increasing the liquidity. We further study possible cross-sectional variations of the effect of investor attention on idiosyncratic risk. Evidence shows that the investor attention effect is more pronounced for smaller-cap and younger cryptocurrencies. Moreover, a relatively stable external market environment and rising market state are conducive to the further play of the attention effect.
\end{abstract}

\section{ARTICLE HISTORY}

Received 29 December 2020

Accepted 29 September 2021

\section{KEYWORDS}

Cryptocurrency; investor attention; idiosyncratic risk; liquidity

\section{JEL CLASSIFICATIONS}

G10; G12

\section{Introduction}

Since Ang et al. (2006) presented their research results on the significant negative relationship between idiosyncratic risk and cross-sectional returns of stocks, the testing and analysis of idiosyncratic risk has become one of the hot issues in the field of asset pricing. For the last decade, many studies have been trying to find theoretical explanation and empirical evidence for such phenomena (Cao, Simin, and Zhao 2008; Fu 2009; Kang, Kondor, and Sadka 2014). Collectively, extant studies all argue that compared to systematic risk, idiosyncratic risk reflects the risk unique to the asset itself, which should be paid more attention to.

Similar to the case of traditional financial assets, relevant studies on idiosyncratic risk in the cryptocurrency markets can help investors reduce risk related to cognitive biases and provide theoretical basis for the construction of the portfolio investment strategies. Meanwhile, idiosyncratic risk in cryptocurrency markets is closely related to the information transparency as well as the investors' interest, thus the improvement of relevant research is conducive to promote the information environment of cryptocurrency markets, so as to better protect the interests of investors and promote the activity of market transactions. However, even though numerous studies have explored the systemic risk, such as the role of volatility in the cryptocurrency market (Katsiampa 2017; Urquhart 2017; Baur and Dimpfl 2018; Yi, Xu, and Wang 2018; Katsiampa 2019), research on idiosyncratic risk remains scarce. Recently, Zhang and $\mathrm{Li}$ (2020) explore the pricing effect of idiosyncratic risk in the cryptocurrency markets. They find that idiosyncratic risk is a significant pricing factor in the cryptocurrency market and can yield significant positive returns.

Different from Zhang and $\mathrm{Li}$ (2020), the purpose of this paper is to investigate the impact of investor attention on idiosyncratic risk in the cryptocurrency markets. The efficient market hypothesis (EMH) assumes that the information processing capacity of market participants is unlimited and that all public information in the market can be fully reflected in the stock price. However, since the 1970s, many studies (e.g. Kahneman and Tversky

CONTACT Feiyang Cheng fycheng@tju.edu.cn

(1) Supplemental data for this article can be accessed here. https://doi.org/10.1080/1351847X.2021.1989008

๑) 2021 Informa UK Limited, trading as Taylor \& Francis Group 
(1973), Merton (1987), and Barber and Odean (2008)) consider that attention is in practice a scarce resource and investors mostly hold only a subset of assets. Extant studies also point out that investors' limited attention affects trading behavior and, ultimately, asset prices. For example, Kahneman and Tversky (1973) argue that individual attention can reflect the degree of information input and meet people's needs for information acquisition. When investors actively collect and utilize information, the information is reflected in asset prices more quickly and comprehensively (Da, Engelberg, and Gao 2011). Therefore, investor attention can change the degree to which investors respond to market information and influence their trading behavior (DellaVigna and Pollet 2009; Vozlyublennaia 2014; Yuan 2015; Li, Hendler, and Teall 2016). Based on the above research, Cheng et al. (2020) also show that assets with high investor attention tend to have higher trading activity and liquidity. Meanwhile, investor attention can also promote the market to better play the role of price discovery and reduce price distortion caused by information asymmetry in turn (Hirshleifer, Teoh, and Yu 2011; Andrei and Hasler 2015).

Consistent with the traditional financial assets, extant studies point out that investor attention also plays significant role in the cryptocurrency markets, especially in the Bitcoin market. For example, taking Google trends, Twitter posts and Wikipedia searches as the measure of investor attention, Aallborg, Molnár, and de Vries (2019), Dastgir et al. (2019) and Shen, Urquhart, and Wang (2019) find that investor attention can significantly predict the trading volume and realized volatility in the next trading day. Besides, Zhang and Wang (2020) find that higher investor attention is positively related to higher returns in the Bitcoin market. In all, the above findings are all in line with Kristoufek (2013) and Liu and Tsyvinski (2018), indicating that the relationship between Bitcoin price and investor attention is significantly important for Bitcoin price discovery, thus it is indeed vital to explore the impact of attention in Bitcoin's pricing process.

Moreover, some studies also explore the possible mechanisms by which investor attention plays a role in the cryptocurrency market. Specifically, Lammer, Hanspal, and Hackethal (2019) find that the average cryptocurrency investor substantially increases log-in and trading activity after his or her first cryptocurrency purchase, which may play important role in the attention effect. Choi (2020) point out that active investor attention from informed traders would actively generate and reproduce information and finally improve the liquidity level of Bitcoin. Different from them, following the attention-inefficiency relationship proposed by Urquhart (2016), Wei (2018), and Tiwari et al. (2018), Ibikunle, McGroarty, and Rzayev (2020) explore whether and how increased attention affects the price discovery process of Bitcoin market. After decomposing Bitcoin price into efficient and noise components, they find that the noise element of Bitcoin pricing is driven by high levels of attention. Similarly, Subramaniam and Chakraborty (2020) provide evidence of attention-induced price pressure hypothesis in the prices of cryptocurrencies during expansionary phases and fear selling during poor market performance, verifying the investor attention effect on investors' trading behavior.

Following the recent literature, there may be a dual impact of investor attention on the idiosyncratic risk of cryptocurrencies. On the one hand, parallel to the stock markets, similar behavioral biases are also present in new virtual currency markets (Grobys and Junttila 2020). For example, literature argues that speculation is an important character of the cryptocurrency markets (Garcia et al. 2014). Given the scarcity of attention resources, investors may speculate on the cryptocurrencies that attract their attention (Aallborg, Molnár, and de Vries 2019; Dastgir et al. 2019; Figa-Talamanca and Patacca 2019). Thus, similar to the stock markets, the irrational investor sentiment and excessive trading behavior induced by investor attention may exacerbate the idiosyncratic volatility and risk of cryptocurrencies. On the other hand, liquidity plays an important role in the cryptocurrency market, which is one of the important factors that determine the direction of its price (Koutmos 2018). Koutmos (2018) and Dong et al. (2020) also point out that compared to a handful of popular cryptocurrencies, the cryptocurrency market as a whole remains relatively illiquid. However, Choi (2020) suggests that active investor attention can significantly improve Bitcoin liquidity in real time. That is, the higher liquidity there is, the more continuous transactions will be in the cryptocurrency market, thus reducing the idiosyncratic volatility. Alternatively, it is possible that investor attention will reduce idiosyncratic volatility in the cryptocurrency market by increasing liquidity.

Different from the existing literature that only adopt Bitcoin or a few cryptocurrencies as the research object, this paper takes all the actively traded sample in the cryptocurrency markets from the year 2013 to 2020 as the research object to explore the impact of investor attention on idiosyncratic risk. Accordingly, empirical evidence 
shows that investor attention can significantly reduce the idiosyncratic risk in the cryptocurrency market. This result still holds after a series of robustness checks. More importantly, the above negative relationship between investor attention and idiosyncratic risk still significantly exists in the long-term. Meanwhile, we also investigate the potential channels that link investor attention and idiosyncratic risk. The channel analysis results indicate that investor attention reduces idiosyncratic risk by increasing the liquidity level of the cryptocurrency markets, validating the important role of liquidity. Finally, we study possible cross-sectional variations of the effect of investor attention on idiosyncratic risk from the perspective of cryptocurrency characteristics and aggregate states. Evidence shows that the attention effect is more pronounced for those smaller-cap and younger cryptocurrencies, and relatively stable external market environment and rising market state are conducive to the further play of the attention effect.

This paper contains four main contributions. First, the conclusions in this paper extend the research on idiosyncratic risks in the cryptocurrency market. It is widely accepted that idiosyncratic risk is an important pricing factor in the stock market, and a series of studies have explored the role of stocks' idiosyncratic risks (Ang et al. 2006; Bali and Cakici 2008; Jiang, Xu, and Yao 2009). However, as an emerging trading market, while there is a vast literature exploring the volatility of cryptocurrency markets (Urquhart 2017; Katsiampa 2019; Walther, Klein, and Bouri 2019; Katsiampa 2019; Fang, Su, and Yin 2020), there have been relatively few studies on the idiosyncratic risk of the cryptocurrency market, and the results have been controversial. Zhang and Li (2020) find that idiosyncratic risk has a positive and significant pricing effect in the cryptocurrency markets. In contrast, Liu, Tsyvinski, and Wu (2019) and Long et al. (2020) indicate that idiosyncratic risk does not show a significant pricing effect in the cryptocurrency market. Different from the above ideas, Borri (2019) points out that several major cryptocurrency assets such as Bitcoin are highly exposed to tail-risk within crypto markets. Moreover, he emphasizes that the idiosyncratic risk of cryptocurrencies can be significantly reduced by holding diversified cryptocurrency assets portfolio. Unlike the above studies, we explore the impact factors of idiosyncratic risk in the cryptocurrency markets from the perspective of investor behavior. Our results suggest that investor attention can improve the liquidity of cryptocurrency markets and thus reduce the idiosyncratic risk of cryptocurrency assets. Our findings are important for understanding the impact factors of idiosyncratic risks as well as the internal characteristics of cryptocurrency markets, which can provide further support for the investors interest protection.

Second, this paper provides a reference for resolving the debate about the role of investor attention in the cryptocurrency market. Specifically, the price-investor attention relationship in cryptocurrency markets is vital for the cryptocurrency price discovery and is deserving of academic inquiries (Kristoufek 2013; Ibikunle, McGroarty, and Rzayev 2020). However, the conclusions concerning the impact of investor attention is contradictory. On the one hand, Ibikunle, McGroarty, and Rzayev (2020) investigate how increased attention affects Bitcoin's price discovery process. By decomposing bitcoin price into efficient and noise components, their results show that the noise element of Bitcoin pricing is driven by high levels of attention. This implies that high levels of attention are linked with an increase in uninformed trading activity in the market for Bitcoin, while informed trading activity is driven by arbitrage rather than attention. On the other hand, Liu and Tsyvinski (2018) argue that the impact of investor attention on price is one of the most important and unique characteristics of cryptocurrency markets. Shen, Urquhart, and Wang (2019) also find that investor attention (measured by Twitter posts) is a significant driver of next day realized volatility. In addition, there are some extant studies arguing that attention itself offers no significant predictive power in forecasting volatility and volume (Urquhart 2018). Through careful analysis, it is clear that the above studies only use Bitcoin as the research object to analyze the role of investor attention, which cannot effectively avoid the impact of sample selection bias on empirical results. On the contrary, using market-wide data, we show that investor attention can indeed effectively promote the improvement of the liquidity level of cryptocurrency, thus reducing its idiosyncratic risk and promoting the stable and orderly development of the whole market. Our results have important implications for a more comprehensive understanding of the role of investor attention in the cryptocurrency market, especially the role of investor attention in the cryptocurrency market at an overall level.

Third, this paper complements the internal mechanism by which investor attention works in the cryptocurrency markets. We find that, in comparison to the irrational and speculative trading behavior induced by investor attention in the stock markets (Barber and Odean 2008; Cheng et al. 2020), investor attention can significantly 
improve the liquidity level of cryptocurrencies. This also shows that for the illiquid market such as cryptocurrency markets, investor attention can effectively restrain the volatility of asset prices caused by illiquidity, which support the relationship between attention and liquidity in the cryptocurrency markets mentioned by Choi (2020).

Finally, the findings of heterogeneity analyses in this paper also provide a reference for how to effectively enhance the positive effect of investor attention in the cryptocurrency markets. We find that the cryptocurrency size, listing age, and external aggregate states have an impact on the relationship between investor attention and idiosyncratic risk. The above conclusions can provide an effective reference for different cryptocurrencies and exchanges in different situations to correctly guide market attention and make them play a positive role.

The rest of the paper is organized as follows. Section 2 provides data source, sample selection rule and the baseline model. Section 3 reports our empirical results and channel analysis. In Section 4, we conduct additional analyses on the relationship between investor attention and idiosyncratic risk in the cryptocurrency markets from the perspective of different cryptocurrency characteristics, external environment, and aggregate states. Section 5 concludes the paper.

\section{Data and methodology}

\subsection{Data source and sample selection}

The trading data of cryptocurrencies used in this paper is obtained from Coinmarketcap (www.coinmarket cap.com). Coinmarketcap (CMC) is an important data source of cryptocurrency research (Subramaniam and Chakraborty 2020). CMC continuously provides the latest information about the total value of the cryptocurrency market, the current price of cryptocurrency and the trade volume through API. The investor attention data is obtained from Google Trends website (www.google.com/trends). Considering the impact of some missing values on the estimation, we exclude the cryptocurrencies with trading days less than 365 and more than half of Google search volume is zero in the sample range. Finally, we get 9357 observations covering the period from 30 April 2013 to 30 November 2020.

Our dataset includes 452 cryptocurrencies denominated in US dollar as the research objects, including Bitcoin, Ethereum, XRP, Tether, Litecoin, and so on. These cryptocurrencies with active transactions account for more than $95 \%$ of the total market value during the sample period, which roughly reflects the overall picture of the cryptocurrency market. All continuous variables are winsorized by $1 \%$ to eliminate the outlier effect. The detailed sample distribution is provided in Appendix (Table A2), including the number of observations each year and the list of cryptocurrencies' names.

\subsection{Main variables}

\subsubsection{Investor attention}

Google Trends (http://www.google.com/trends) provides detailed data on the frequency of term searches. It shows how many times the viewers have searched for a particular keyword over a period of time. Specifically, before the researcher can get the search value of a specific term, she must first select the search time interval, search term source region, and the field of the search word. Under the above multiple selected conditions, the maximum search value SVI in the interval is set to 100 , and other values are directly standardized according to this value. Finally, the search volume index (SVI) obtained by the searcher is from 0 to 100 . As for our study, the search area that we selected is global, and the search term that we selected belongs to the financial field.

Referring to Ding and Hou (2015) and Bystrom and Krygier (2018), we use the natural logarithm of search volume index (SVI) provided by Google Trends as the proxy variable of investor attention denoted by 'Attention'. Specifically, we use the full name of cryptocurrency as the search keyword and get the daily data from 30 April 2013 to 30 November 2020. The data range is set to the global search volume of all categories. Finally, in order to be consistent with the frequency of idiosyncratic risk, we use the daily data to calculate the monthly mean, and then calculate its natural logarithm. Figure 1 shows the Google Trends page with Bitcoin as an example. 


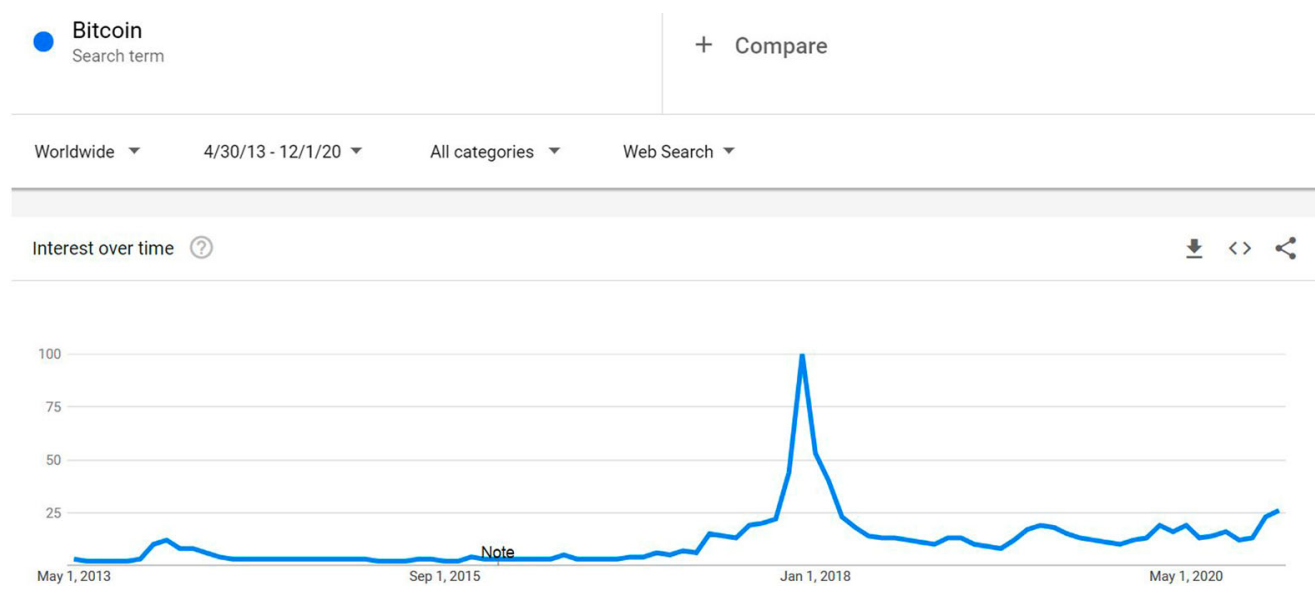

Figure 1. Google Trends of Bitcoin. This chart plots the number of Google Search Volume Index of 'Bitcoin' worldwide from April 30, 2013 to November 30, 2020, based on daily web searches adopting 'Bitcoin' as the key word.

\subsubsection{Idiosyncratic risk}

According to the previous literature, we assume that a cryptocurrency return is driven by a common factor and its own specific shocks (Zhang and Li 2020). We use a method similar to the traditional CAPM model to measure the idiosyncratic risk of a cryptocurrency:

$$
R_{i, d}-r_{f, d}=\alpha_{i, d}+\beta_{i, d}\left(R_{m, d}-r_{f, d}\right)+\varepsilon_{i, d}
$$

The within-month daily return data is used to estimate the Equations (1) and (2). Where $R_{i, d}$ is the return on cryptocurrency $i$ in day $d$ in a given month; $r_{f, d}$ is the risk-free interest rate in day $d$ in a given month where we use the return of US Treasury bills to measure it; $R_{m, d}$ is the returns on the market in day $d$ in a given month which is calculated by value-weighted method; $\varepsilon_{i, d}$ is the residual term. Then, we use the standard deviation of the residual term to calculate the monthly idiosyncratic volatility of cryptocurrency $i$ :

$$
\mathrm{IVOL}_{i, t}=\sqrt{\operatorname{Var}\left(\varepsilon_{i, d, t}\right)}
$$

\subsubsection{Cryptocurrency liquidity}

Amihud (2002) illiquidity is commonly used to measure asset liquidity in majority studies (Loi 2018; Scharnowski 2020; Tinic et al. 2020). The specific measurement method is the average ratio between the absolute value of the daily return rate and the daily transaction amount over the trading days. Amihud considers the velocity, width, and depth of the liquidity, which can reflect the size of the three-dimensional compound liquidity. The calculation method is as follows:

$$
\text { Amihud }=\frac{1}{N} \sum_{d=1}^{N} \frac{\left|r_{d}\right|}{Q_{d} / 10^{6}}
$$

where $r_{d}$ is the daily return rate, $Q_{d}$ is the daily dollar transaction amount, $N$ is the number of trading days within a month. When the ILLIQ increases, the illiquidity of the market increases, that is, the liquidity of the market decreases.

\subsubsection{Other control variables}

In order to analyze the real impact of investor attention on the idiosyncratic risk of cryptocurrencies, following the relevant literature (Harvey and Siddique 2000; Yao et al. 2019; Ibikunle, McGroarty, and Rzayev 2020; Subramaniam and Chakraborty 2020), we calculate and control for the following variables in our empirical model: 
(1) Size: the natural logarithm of the market value; (2) Volume: the logarithm of trading volume; (3) Mom: the momentum of each cryptocurrency in month $t$ is measured by the cumulative return from month $t$-11 to month $t-1$; (4) Reverse: the return on the cryptocurrency over the previous month; (5) Coskew: according to the Equation (4) for each cryptocurrency within each year, the co-skewness of cryptocurrency $i$ in month $t$ is defined as the coefficient $\hat{\gamma}_{i}$; (6) Iskew: the idiosyncratic skewness of cryptocurrency $i$ in month $t$ which is defined as the skewness of the residuals of Equation (4); (7) MAX: the maximum daily return in month $t$.

$$
R_{i, d}-r_{f, d}=\alpha_{i, d}+\beta_{i, d}\left(R_{m, d}-r_{f, d}\right)+\gamma_{i, d}\left(R_{m, d}-r_{f, d}\right)^{2}+\varepsilon_{i, d}
$$

\subsection{Regression model}

To examine the investor attention on cryptocurrencies' idiosyncratic risk, we construct the following model:

$$
\operatorname{IVOL}_{i, t}=\beta_{0}+\beta_{1} * \text { Attention }_{i, t-1}+\sum_{k} \gamma_{k} \operatorname{Control}_{k, i, t-1}+\sum \text { Cryptocurrency }+\sum \text { Month }+\varepsilon_{i, t}
$$

To mitigate possible causality and endogeneity problems, all the independent variables are lagged by one month relative to the month on which the dependent variable is measured. Where $\mathrm{IVOL}_{i, t}$ is the idiosyncratic risk of cryptocurrency $i$ in month $t$; Attention ${ }_{i, t-1}$ is the proxy variable of investor attention of cryptocurrency $i$ in month $t_{-} 1$; Control $\mathrm{C}_{k, i, t-1}$ is a set of control variables that are defined in the previous section; $\sum$ Cryptocurrency, $\sum$ Month indicate that we also control our model for the cryptocurrency fixed effects and year fixed effects. The standard errors are clustered at the cryptocurrency level, as discussed by Petersen (2009). This paper mainly observes the significance level of $\beta_{1}$ in Equation (5). A significant negative coefficient means that investor attention limits the idiosyncratic risk of cryptocurrency. Otherwise, investor attention aggravates the idiosyncratic risk.

\section{Empirical results}

\subsection{Descriptive statistics and correlation coefficients}

The descriptive statistics and correlation analysis are shown in Tables 1 and 2 respectively. It can be seen from Table 1 that the idiosyncratic risk of cryptocurrency is 0.536 , and the mean is much higher than that of the stock markets in different countries or regions listed in Ang et al. (2006). ${ }^{1}$ The standard deviation is 0.597, which means that the volatility of different cryptocurrencies varies greatly. The average investor attention is about 41 , that is, the average monthly search intensity of each cryptocurrency on Google Trends is 41 (the maximum is 100). In addition, the statistical results of other control variables are also in normal range.

According to the correlation results in Table 2, there is a significant negative correlation between investor attention and idiosyncratic risk $(p<0.01)$, that is, cryptocurrencies that are highly searched tend to have lower

Table 1. Descriptive statistics.

\begin{tabular}{lcccccc}
\hline Variable & $N$ & Mean & Std. dev & Min & Median & Max \\
\hline IVOL $_{t}$ & 9357 & 0.536 & 0.597 & 0.066 & 0.351 & 4.139 \\
Attention $_{t-1}$ & 9357 & 3.725 & 0.593 & 1.841 & 3.844 & 4.498 \\
Size $_{t-1}$ & 9357 & 15.71 & 2.918 & 9.215 & 15.64 & 23.43 \\
Volume $_{t-1}$ & 9357 & 11.50 & 4.390 & 1.004 & 11.60 & 21.92 \\
MOM $_{t-1}$ & 9357 & 1.550 & 5.484 & -0.947 & -0.458 & 21.61 \\
Reverse $_{t-1}$ & 9357 & 0.090 & 0.614 & -0.667 & -0.045 & 3.489 \\
Coskew $_{t-1}$ & 9357 & -1.866 & 12.36 & -52.80 & -1.002 & 50.91 \\
Iskew $_{t-1}$ & 9357 & 0.702 & 1.012 & -1.441 & 0.550 & 4.118 \\
MAX $_{t-1}$ & 9357 & 0.327 & 0.448 & 0.0300 & 0.188 & 3.149 \\
\hline
\end{tabular}

Notes: This table displays descriptive statistics for the variables. The sample is merged across two databases, Coinmarketcap and Google Trends over the period from 30 April 2013 to 30 November 2020. Mean, standard deviation, minimum, median, and maximum of each variable is reported. The definitions of variables are provided in the Appendix. All data are monthly. 
Table 2. Pearson correlation coefficients.

\begin{tabular}{|c|c|c|c|c|c|c|c|c|}
\hline & $\mathrm{IVOL}_{t}$ & Attention $_{t-1}$ & Size $_{t-1}$ & Volume $_{t-1}$ & $\mathrm{MOM}_{t-1}$ & Reverse $_{t-1}$ & Coskew $_{t-1}$ & Iskew $_{t-1}$ \\
\hline Attention $_{t-1}$ & $-0.031^{* * *}$ & & & & & & & \\
\hline Size $_{t-1}$ & $-0.429^{* * *}$ & $0.023^{* *}$ & & & & & & \\
\hline Volume $_{t-1}$ & $-0.064^{* * *}$ & $0.031^{* * *}$ & $0.250^{* * *}$ & & & & & \\
\hline $\mathrm{MOM}_{t-1}$ & $0.041^{* * *}$ & -0.001 & $-0.029^{* * *}$ & -0.003 & & & & \\
\hline Reverse $_{t-1}$ & 0.012 & -0.005 & -0.007 & -0.001 & -0.001 & & & \\
\hline Coskew $_{t-1}$ & $-0.023^{* *}$ & -0.010 & 0.010 & 0.005 & -0.001 & 0.002 & & \\
\hline Iskew $_{t-1}$ & $0.108^{* * *}$ & 0.008 & $-0.103^{* * *}$ & $-0.044^{* * *}$ & $0.033^{* * *}$ & 0.004 & $-0.071^{* * *}$ & \\
\hline $\mathrm{MAX}_{t-1}$ & $0.049 * * *$ & -0.005 & $-0.055^{* * *}$ & -0.005 & 0.005 & 0.000 & $-0.012^{* * *}$ & $0.109^{* * *}$ \\
\hline
\end{tabular}

Notes: This table reports the Pearson correlations between the regression variables. The superscript asterisks $* * *, * *$ and $*$ denote two-tailed statistical significance at the $1 \%, 5 \%$ and $10 \%$ levels, respectively. The definitions of variables are provided in the Appendix. All data are monthly.

Table 3. The impact of the investor attention on cryptocurrency's idiosyncratic risk.

\begin{tabular}{|c|c|c|c|c|c|c|c|c|}
\hline & \multicolumn{8}{|c|}{ Dependent variable $=\mathrm{IVOL}_{t}$} \\
\hline & (1) & (2) & (3) & (4) & (5) & (6) & (7) & (8) \\
\hline Attention $_{t-1}$ & $\begin{array}{c}-0.053^{* * *} \\
(-3.933)\end{array}$ & $\begin{array}{c}-0.037^{* * *} \\
(-2.836)\end{array}$ & $\begin{array}{c}-0.038^{* * *} \\
(-2.871)\end{array}$ & $\begin{array}{c}-0.037^{* * *} \\
(-2.837)\end{array}$ & $\begin{array}{c}-0.038^{* * *} \\
(-2.852)\end{array}$ & $\begin{array}{c}-0.037^{* * *} \\
(-2.840)\end{array}$ & $\begin{array}{c}-0.037^{* * *} \\
(-2.835)\end{array}$ & $\begin{array}{c}-0.038^{* * *} \\
(-2.894)\end{array}$ \\
\hline Size $_{t-1}$ & & $\begin{array}{l}-0.375^{* * *} \\
(-10.462)\end{array}$ & $\begin{array}{l}-0.365^{* * *} \\
(-10.146)\end{array}$ & $\begin{array}{l}-0.374^{* * *} \\
(-10.452)\end{array}$ & $\begin{array}{c}-0.376^{* * *} \\
(-10.509)\end{array}$ & $\begin{array}{l}-0.368^{* * *} \\
(-10.252)\end{array}$ & $\begin{array}{l}-0.374^{* * *} \\
(-10.430)\end{array}$ & $\begin{array}{l}-0.363^{* * *} \\
(-10.071)\end{array}$ \\
\hline Volume $_{t-1}$ & & $\begin{array}{c}-0.116^{* * *} \\
(-4.989)\end{array}$ & $\begin{array}{c}-0.119^{* * *} \\
(-5.081)\end{array}$ & $\begin{array}{c}-0.116^{* * *} \\
(-4.989)\end{array}$ & $\begin{array}{c}-0.115^{* * *} \\
(-4.928)\end{array}$ & $\begin{array}{c}-0.117^{* * *} \\
(-5.030)\end{array}$ & $\begin{array}{c}-0.116^{* * *} \\
(-4.969)\end{array}$ & $\begin{array}{c}-0.119^{* * *} \\
(-5.088)\end{array}$ \\
\hline $\mathrm{MOM}_{t-1}$ & & & $\begin{array}{c}0.122^{* * *} \\
(2.678)\end{array}$ & & & & & $\begin{array}{c}0.119^{* * *} \\
(2.610)\end{array}$ \\
\hline Reverse $_{t-1}$ & & & & $\begin{array}{l}-0.002 \\
(-0.328)\end{array}$ & & & & $\begin{array}{c}-0.002 \\
(-0.293)\end{array}$ \\
\hline Coskew $_{t-1}$ & & & & & $\begin{array}{c}-0.040^{* * *} \\
(-5.348)\end{array}$ & & & $\begin{array}{c}-0.048^{* * *} \\
(-5.521)\end{array}$ \\
\hline Iskew $_{t-1}$ & & & & & & $\begin{array}{c}0.023^{* * *} \\
(2.895)\end{array}$ & & $\begin{array}{c}0.021^{* * *} \\
(2.602)\end{array}$ \\
\hline $\mathrm{MAX}_{t-1}$ & & & & & & & $\begin{array}{c}0.303 \\
(1.009)\end{array}$ & $\begin{array}{c}-0.745^{* *} \\
(-2.142)\end{array}$ \\
\hline Constant & $\begin{array}{c}0.353 \\
(1.566)\end{array}$ & $\begin{array}{c}-0.026 \\
(-0.118)\end{array}$ & $\begin{array}{c}-0.020 \\
(-0.089)\end{array}$ & $\begin{array}{l}-0.026 \\
(-0.117)\end{array}$ & $\begin{array}{c}0.016 \\
(0.071)\end{array}$ & $\begin{array}{l}-0.027 \\
(-0.120)\end{array}$ & $\begin{array}{c}-0.023 \\
(-0.102)\end{array}$ & $\begin{array}{c}0.290 \\
(1.267)\end{array}$ \\
\hline Crypt FE & Yes & Yes & Yes & Yes & Yes & Yes & Yes & Yes \\
\hline Month FE & Yes & Yes & Yes & Yes & Yes & Yes & Yes & Yes \\
\hline Observations & 9,357 & 9,357 & 9,357 & 9,357 & 9,357 & 9,357 & 9,357 & 9,357 \\
\hline Adjusted $\mathrm{R}^{2}$ & 0.063 & 0.091 & 0.091 & 0.091 & 0.093 & 0.094 & 0.091 & 0.095 \\
\hline
\end{tabular}

idiosyncratic risk. In addition, the correlations between all control variables are relatively low, the untabulated results of multicollinearity test also show that most variance inflation factor (VIF) values is less than 1.50, far less than the critical value of 10 . Therefore, there is no serious multicollinearity problem in the regression model.

\subsection{Baseline results}

Table 3 presents the baseline regression results of Equation (5). As reported in Column 1, the coefficient on Attention $_{i, t-1}$ is significantly negative. To verify the robustness of our empirical results, we also conduct panel data analysis with controls for well-known determinants of idiosyncratic risk under a multivariate regression framework. For example, we add the most common control variables Size ${ }_{i, t-1}$ and Volume Vit-1 $_{\text {in Column } 2 .}$ Then, Columns 3-7 show the regression results of adding $\mathrm{MOM}_{i, t-1}$, Reverse $_{i, t-1}$, COSkew $_{i, t-1}, \mathrm{ISkew}_{i, t-1}$, and $\mathrm{MAX}_{i, t-1}$ on the basis of Column 2 respectively. The above regression results show that the coefficients on Attention $_{i, t-1}$ are all significantly negative, which verify that investor attention can reduce idiosyncratic risk. 
Table 4. The impact of investor attention on idiosyncratic risk in the long-term.

\begin{tabular}{|c|c|c|c|c|c|}
\hline & $\mathrm{IVOL}_{t+1}$ & $\mathrm{IVOL}_{t+2}$ & $\mathrm{IVOL}_{t+3}$ & $\mathrm{IVOL}_{t+4}$ & $\mathrm{IVOL}_{t+5}$ \\
\hline Dependent variable $=$ & (1) & $(2)$ & (3) & (4) & (5) \\
\hline Attention $_{t-1}$ & $\begin{array}{c}-0.043^{* * *} \\
(-3.103)\end{array}$ & $\begin{array}{c}-0.035^{* *} \\
(-2.398)\end{array}$ & $\begin{array}{c}-0.036^{* *} \\
(-2.416)\end{array}$ & $\begin{array}{c}-0.034^{* *} \\
(-2.158)\end{array}$ & $\begin{array}{c}-0.025 \\
(-1.567)\end{array}$ \\
\hline Size $_{t-1}$ & $\begin{array}{c}-0.292^{* * *} \\
(-7.617)\end{array}$ & $\begin{array}{c}-0.269^{* * *} \\
(-6.700)\end{array}$ & $\begin{array}{c}-0.310^{* * *} \\
(-7.398)\end{array}$ & $\begin{array}{c}-0.360^{* * *} \\
(-8.214)\end{array}$ & $\begin{array}{c}-0.312^{\text {*** }} \\
(-6.867)\end{array}$ \\
\hline Volume $_{t-1}$ & $\begin{array}{c}-0.089^{* * * *} \\
(-3.568)\end{array}$ & $\begin{array}{c}-0.060^{* *} \\
(-2.293)\end{array}$ & $\begin{array}{l}-0.028 \\
(-1.020)\end{array}$ & $\begin{array}{c}0.061^{* *} \\
(2.138)\end{array}$ & $\begin{array}{c}0.016 \\
(0.543)\end{array}$ \\
\hline $\mathrm{MOM}_{t-1}$ & $\begin{array}{l}0.092^{*} \\
(1.955)\end{array}$ & $\begin{array}{c}0.039 \\
(0.825)\end{array}$ & $\begin{array}{c}-0.059 \\
(-1.235)\end{array}$ & $\begin{array}{c}0.051 \\
(1.071)\end{array}$ & $\begin{array}{c}-0.007 \\
(-0.153)\end{array}$ \\
\hline Reverse $_{t-1}$ & $\begin{array}{l}-0.005 \\
(-0.637)\end{array}$ & $\begin{array}{c}0.009 \\
(1.296)\end{array}$ & $\begin{array}{c}-0.015^{* *} \\
(-2.099)\end{array}$ & $\begin{array}{c}-0.012 \\
(-1.597)\end{array}$ & $\begin{array}{c}0.064^{* * *} \\
(8.571)\end{array}$ \\
\hline Coskew $_{t-1}$ & $\begin{array}{c}-0.030^{* *} \\
(-2.506)\end{array}$ & $\begin{array}{c}0.012 \\
(1.001)\end{array}$ & $\begin{array}{l}-0.002 \\
(-0.185)\end{array}$ & $\begin{array}{l}-0.018 \\
(-1.308)\end{array}$ & $\begin{array}{c}0.058^{* * *} \\
(4.146)\end{array}$ \\
\hline Iskew $_{t-1}$ & $\begin{array}{c}0.006 \\
(0.751)\end{array}$ & $\begin{array}{c}-0.002 \\
(-0.283)\end{array}$ & $\begin{array}{c}0.014 \\
(1.574)\end{array}$ & $\begin{array}{l}-0.004 \\
(-0.402)\end{array}$ & $\begin{array}{c}-0.024^{* *} \\
(-2.477)\end{array}$ \\
\hline $\mathrm{MAX}_{t-1}$ & $\begin{array}{l}-0.587 \\
(-1.582)\end{array}$ & $\begin{array}{l}-0.026 \\
(-0.068)\end{array}$ & $\begin{array}{c}0.078 \\
(0.199)\end{array}$ & $\begin{array}{c}-1.235^{* * * *} \\
(-3.086)\end{array}$ & $\begin{array}{l}0.804^{* *} \\
(2.010)\end{array}$ \\
\hline Constant & $\begin{array}{l}-0.196 \\
(-0.862)\end{array}$ & $\begin{array}{c}-0.074 \\
(-0.327)\end{array}$ & $\begin{array}{c}-0.269 \\
(-1.178)\end{array}$ & $\begin{array}{c}0.165 \\
(0.719)\end{array}$ & $\begin{array}{c}-0.127 \\
(-0.559)\end{array}$ \\
\hline Crypt FE & Yes & Yes & Yes & Yes & Yes \\
\hline Month FE & Yes & Yes & Yes & Yes & Yes \\
\hline Observations & 8,810 & 8,300 & 7,821 & 7,372 & 6,949 \\
\hline Adjusted $\mathrm{R}^{2}$ & 0.081 & 0.077 & 0.081 & 0.083 & 0.099 \\
\hline
\end{tabular}

Notes: This table presents that the impact of investor attention on idiosyncratic risk from $t+2$ to $t+6$. The detailed definitions of the above variables are shown in the Appendix. All continuous variables are winsorized at $1 \%$ and $99 \%$. The standard errors are clustered at the cryptocurrency level, as discussed by Petersen (2009). $t$-statistics are given in the parentheses. ${ }^{*}, * *$, and ${ }^{* * *}$ indicate significance at the $10 \%, 5 \%$, and $1 \%$ levels, respectively. Our sample period is from 30 April 2013 to 30 November 2020. All data are monthly.

At the same time, the coefficients of control variables are consistent with previous studies. For example, the regression coefficient of the Size $e_{i, t-1}$ is -0.363 , which is negative at the significance level of $1 \%$. This result indicates that the larger the scale of cryptocurrency, the lower the idiosyncratic risk level. The regression coefficients on cryptocurrency market value (Volume $e_{i, t-1}$ ) is -0.027 and $t$-value is -5.088 . Meanwhile, it can be seen from the baseline regression results that the greater the MOM of cryptocurrency, the higher the idiosyncratic risk. In addition, the characteristics of cryptocurrency such as higher co-skewness (Coskew $i, t-1)$, lower idiosyncratic skewness $\left(\mathrm{Iskew}_{i, t-1}\right)$ and higher max effect $\left(\mathrm{MAX}_{i, t-1}\right)$ are related to lower idiosyncratic risk.

\subsection{The long-term effect of investor attention}

After confirming the negative effect of investor attention on idiosyncratic risk in the short term, next of interest is the persistence of the negative effect over longer time horizons. The research on the long-term relationship between investor attention and idiosyncratic risk can also help us further understand whether the role of investor attention exists only in the short term, or whether it has long-term market effect. Using the two-way fixed effects regression, we explore the impact of investor attention on the idiosyncratic risk from $t+1$ to $t+5$, and the regression results in Table 4 present that the negative effect of investor attention on idiosyncratic risk still exist from $t+1$ to $t+4$. At the same time, the absolute value of the investor attention coefficient shows a downward trend, thus, the impact of investor attention on idiosyncratic risk gradually weakens in the long run. Finally, in the $t+5$ period, the effect of investor attention is no longer significant. In order to verify the robustness of the above results, we also examine the relationship between investor attention and idiosyncratic risk in the $t+6, t+7$ period. The untabulated results show that the effect of investor attention is no longer significant.

The above results show that investor attention can not only decrease the idiosyncratic risk of the cryptocurrency market in the short term, but such effect also continues in a certain period of time in the future. Hence, the results further verify the effectiveness of investor attention in stabilizing the cryptocurrency market and reducing market volatility. 
Table 5. Robustness check: Alternative investor attention measure.

\begin{tabular}{|c|c|c|c|c|c|c|c|c|}
\hline & \multicolumn{8}{|c|}{ Dependent variable $=\mathrm{IVOL}_{t}$} \\
\hline & (1) & $(2)$ & (3) & (4) & (5) & (6) & (7) & (8) \\
\hline$A S V_{t-1}$ & $\begin{array}{c}-0.019^{* *} \\
(-2.118)\end{array}$ & $\begin{array}{c}-0.020^{* *} \\
(-2.267)\end{array}$ & $\begin{array}{c}-0.020^{* *} \\
(-2.252)\end{array}$ & $\begin{array}{c}-0.020^{* *} \\
(-2.261)\end{array}$ & $\begin{array}{c}-0.020^{* *} \\
(-2.320)\end{array}$ & $\begin{array}{c}-0.020^{* *} \\
(-2.277)\end{array}$ & $\begin{array}{c}-0.020^{* *} \\
(-2.267)\end{array}$ & $\begin{array}{c}-0.020^{* *} \\
(-2.319)\end{array}$ \\
\hline Size $_{t-1}$ & & $\begin{array}{c}-0.380^{* * *} \\
(-10.619)\end{array}$ & $\begin{array}{l}-0.370^{* * *} \\
(-10.308)\end{array}$ & $\begin{array}{l}-0.380^{* * *} \\
(-10.609)\end{array}$ & $\begin{array}{c}-0.381^{* * *} \\
(-10.666)\end{array}$ & $\begin{array}{c}-0.373^{* * *} \\
(-10.408)\end{array}$ & $\begin{array}{c}-0.379 * * * \\
(-10.586)\end{array}$ & $\begin{array}{c}-0.368^{* * *} \\
(-10.235)\end{array}$ \\
\hline Volume $_{t-1}$ & & $\begin{array}{c}-0.118^{* * *} \\
(-5.039)\end{array}$ & $\begin{array}{c}-0.120^{* * *} \\
(-5.129)\end{array}$ & $\begin{array}{c}-0.118^{* * *} \\
(-5.039)\end{array}$ & $\begin{array}{c}-0.116^{* * *} \\
(-4.978)\end{array}$ & $\begin{array}{c}-0.118^{* * *} \\
(-5.080)\end{array}$ & $\begin{array}{c}-0.117^{* * *} \\
(-5.019)\end{array}$ & $\begin{array}{c}-0.120^{* * *} \\
(-5.137)\end{array}$ \\
\hline $\mathrm{MOM}_{t-1}$ & & & $\begin{array}{c}0.120^{* * *} \\
(2.627)\end{array}$ & & & & & $\begin{array}{c}0.117^{* *} \\
(2.558)\end{array}$ \\
\hline Reverse $_{t-1}$ & & & & $\begin{array}{c}-0.002 \\
(-0.279)\end{array}$ & & & & $\begin{array}{c}-0.002 \\
(-0.243)\end{array}$ \\
\hline Coskew $_{t-1}$ & & & & & $\begin{array}{c}-0.040^{* * *} \\
(-5.363)\end{array}$ & & & $\begin{array}{c}-0.048^{* * *} \\
(-5.536)\end{array}$ \\
\hline Iskew $_{t-1}$ & & & & & & $\begin{array}{c}0.023^{* * * *} \\
(2.899)\end{array}$ & & $\begin{array}{c}0.021^{* * *} \\
(2.607)\end{array}$ \\
\hline $\mathrm{MAX}_{t-1}$ & & & & & & & $\begin{array}{c}0.304 \\
(1.011)\end{array}$ & $\begin{array}{c}-0.747^{* *} \\
(-2.148)\end{array}$ \\
\hline Constant & $\begin{array}{c}0.333 \\
(1.477)\end{array}$ & $\begin{array}{c}-0.046 \\
(-0.205)\end{array}$ & $\begin{array}{l}-0.040 \\
(-0.178)\end{array}$ & $\begin{array}{c}-0.045 \\
(-0.204)\end{array}$ & $\begin{array}{c}-0.046 \\
(-0.208)\end{array}$ & $\begin{array}{c}-0.033 \\
(-0.147)\end{array}$ & $\begin{array}{c}-0.042 \\
(-0.189)\end{array}$ & $\begin{array}{c}0.273 \\
(1.193)\end{array}$ \\
\hline Crypt FE & Yes & Yes & Yes & Yes & Yes & Yes & Yes & Yes \\
\hline Month FE & Yes & Yes & Yes & Yes & Yes & Yes & Yes & Yes \\
\hline Observations & 9,357 & 9,357 & 9,357 & 9,357 & 9,357 & 9,357 & 9,357 & 9,357 \\
\hline Adjusted $\mathrm{R}^{2}$ & 0.062 & 0.090 & 0.091 & 0.090 & 0.093 & 0.091 & 0.090 & 0.095 \\
\hline
\end{tabular}

\subsection{Robustness checks}

\subsubsection{Measurement of detrended Google Trends}

In the previous section, we apply the natural logarithm of SVI from Google Trends to measure investor attention. However, Google Trends Index may have time trends and low-frequency seasonality (Da, Engelberg, and Gao 2011). To reduce data errors and improve the reliability of analysis, we adopt an alternative measure - detrended Google Trends denoted by ASVI. In detail, ASVI not only solves the above problems, but also stably captures the normal level of investor attention. Following Da, Engelberg, and Gao (2011), we calculate the daily abnormal Google Trends Index $\left(\mathrm{ASVI}_{i, t}\right)$ for cryptocurrency $i$ on week $w$ to proxy for an abnormal change in investor attention as follows.

$$
\operatorname{ASVI}_{i, w}=\operatorname{Ln}\left(\mathrm{SVI}_{i, w}\right)-\operatorname{Ln}\left[\operatorname{Med}\left(\mathrm{SVI}_{i, w-1}, \ldots, \mathrm{SVI}_{i, w-8}\right)\right]
$$

where $\mathrm{SVI}_{i, w}$ represents the SVI of cryptocurrency $i$ on week $w$, and $\left[\operatorname{Med}\left(\mathrm{SVI}_{i, w-1}, \ldots, \mathrm{SVI}_{i, w-8}\right)\right]$ is the median value of SVI of cryptocurrency $i$ during the previous eight weeks. As above, to keep consistency with the monthly independent variables, the monthly mean value is taken here. As is shown in Table 5, the regression coefficients of ASVI are still significantly negative at the significance level of 5\%, indicating that the relationship between investor attention and idiosyncratic risk is not affected by the measurement of investor attention.

\subsubsection{Alternative measure of idiosyncratic volatility}

To better explain the composition of cryptocurrency return, following Liu, Liang, and Cui (2020), we also adopt the three-factor model which includes market return, market capitalization, and momentum, to recalculate the idiosyncratic risk of cryptocurrency. The specific calculation approach is shown as follow:

$$
R_{i, d}-r_{f, d}=\alpha_{i, d}+\beta_{i, d}^{\mathrm{MKT}}\left(R_{m, d}-r_{f, d}\right)+\beta_{i, d}^{\mathrm{SMB}} \mathrm{SMB}_{d}+\beta_{i, d}^{\mathrm{MOM}} \mathrm{MOM}_{d}+\varepsilon_{i, d}
$$

Similar to our earlier approach, the within-month daily return data is used to estimate the Equation (7) where $R_{i, d}$ represents the return on cryptocurrency $i$ in day $d$ in a given month; $r_{f, d}$ represents the risk-free interest rate 
in day $d$. We use the return of three-month US Treasury to measure risk-free interest rate; $R_{m, d}$ is the returns on the market in day $d$, which is calculated by value-weighted method; $\mathrm{SMB}_{d}$ is the size factor in day $d ; \mathrm{MOM}_{d}$ represents the momentum factor in day $d$; and $\varepsilon_{i, d}$ is the residual term.

The SMB and MOM in Equation (7) are constructed according to the method of stock market factors provided by Fama and French (1993). First, we build a $3 \times 3$ investment portfolio according to the daily size and momentum. Size is defined as the natural logarithm of the market value in day $d$. Momentum is defined as the momentum of each cryptocurrency in day $d .{ }^{2}$ Samples are divided into three size groups according to the first $30 \%$, middle $40 \%$, and last $30 \%:$ S, M, B. Similarly, they are also divided into three momentum groups: L, $\mathrm{W}, \mathrm{N}$. We then use the intersections of those groups to form value-weighted portfolios for the nine-resulting size-momentum combinations: SW, BW, SN, BN, SL, BL, MN, MW, and ML.

Our size and momentum factors, denoted as SMB (small-minus-big) and WML (winner-minus-loser), are construct as follows:

$$
\begin{aligned}
\mathrm{SMB} & =\frac{S W+S N+S L}{3}-\frac{B W+B N+B L}{3} \\
\mathrm{WML} & =\frac{S W+M W+B W}{3}-\frac{S L+M L+B L}{3}
\end{aligned}
$$

Then, we use the standard deviation of the residual term to calculate the monthly idiosyncratic volatility of cryptocurrency $i$ :

$$
\text { IVOL_FF3 } 3_{i, t}=\sqrt{\operatorname{Var}\left(\varepsilon_{i, d, t}\right)}
$$

As shown in Table 6, the coefficient on investor attention variables are all similar to those reported in Table 3. In detail, after adding all control variables, the regression coefficient of investor attention on idiosyncratic risk is -0.033 , which is significant at the $5 \%$ significance level. These results indicate that after adopting alternative idiosyncratic risk measures, the effect of investor attention on idiosyncratic risk still exists. In addition, the directions of the coefficients of the control variables are the same as previous studies. Thus, our findings do not depend on the applied measures of idiosyncratic risk. These results support Hypothesis 1 again.

\subsubsection{Eliminate the influence of extreme samples}

Due to the great differences in the characteristics of various cryptocurrencies, the more extreme samples may interfere the relationship between investor attention and idiosyncratic risk. Additionally, Smales (2020) suggest that returns for all cryptocurrencies can largely be explained by Bitcoin returns. Thus, to eliminate the impact of small-cap, poor liquidity, young cryptocurrencies, and Bitcoin, we use the median of these indexes in the same month as the grouping standard, and drop those cryptocurrencies with size, liquidity, listing months less than their medians. Then, we re-estimate the fixed effect model. The results in Table 7 show that Attention ${ }_{t-1}$ is still significantly negative at least at the $5 \%$ statistical level. This also gives strong support to Hypothesis 1 .

\subsubsection{Add control variables}

Considering that investor attention is not limited to searching the specific name of cryptocurrency, the impact of the search volume on the results of 'cryptocurrency' or 'digital currency' cannot be ignored. Thus, we use the same calculation method as the main explanatory variables and incorporate the two search keywords into the model to exclude the impact of these general term in cryptocurrency markets. Specifically, Attention_cryptocurrency and Attention_digital are added into the regression model in turn. The results in Columns (1) to (3) of Table 9 show that after adding the above control variables, the core explanatory variables do not change (Table 8$)$.

\subsubsection{Mitigation of endogenous concerns}

One may argue that the investor attention level of a given cryptocurrency may be affected by its own idiosyncratic risk or volatility, which may induce endogeneity concerns. To address the above impact, we adopt the dynamic panel model (GMM) to re-estimate the regression results. Specifically, the idiosyncratic risk of cryptocurrency 
Table 6. Robustness check: Alternative idiosyncratic risk measure.

\begin{tabular}{|c|c|c|c|c|c|c|c|c|}
\hline & \multicolumn{8}{|c|}{ Dependent variable $=\mathrm{IVOL} F F 3_{t}$} \\
\hline & (1) & $(2)$ & (3) & (4) & (5) & (6) & (7) & (8) \\
\hline Attention $_{t-1}$ & $\begin{array}{c}-0.046^{* * *} \\
(-2.956)\end{array}$ & $\begin{array}{l}-0.032^{* *} \\
(-2.061)\end{array}$ & $\begin{array}{l}-0.033^{* *} \\
(-2.092)\end{array}$ & $\begin{array}{l}-0.032^{* *} \\
(-2.061)\end{array}$ & $\begin{array}{l}-0.032^{* *} \\
(-2.089)\end{array}$ & $\begin{array}{l}-0.032^{* *} \\
(-2.064)\end{array}$ & $\begin{array}{l}-0.032^{* *} \\
(-2.059)\end{array}$ & $\begin{array}{c}-0.033^{* *} \\
(-2.132)\end{array}$ \\
\hline Size $_{t-1}$ & & $\begin{array}{c}-0.323^{* * *} \\
(-7.648)\end{array}$ & $\begin{array}{c}-0.313^{* * *} \\
(-7.368)\end{array}$ & $\begin{array}{c}-0.323^{* * *} \\
(-7.637)\end{array}$ & $\begin{array}{c}-0.325^{* * *} \\
(-7.734)\end{array}$ & $\begin{array}{c}-0.314^{* * *} \\
(-7.418)\end{array}$ & $\begin{array}{c}-0.321^{* * *} \\
(-7.599)\end{array}$ & $\begin{array}{c}-0.312^{* * *} \\
(-7.378)\end{array}$ \\
\hline Volume $_{t-1}$ & & $\begin{array}{c}-0.136^{* * *} \\
(-4.929)\end{array}$ & $\begin{array}{c}-0.138^{* * *} \\
(-5.012)\end{array}$ & $\begin{array}{c}-0.136^{* * *} \\
(-4.930)\end{array}$ & $\begin{array}{c}-0.132^{* * * *} \\
(-4.836)\end{array}$ & $\begin{array}{c}-0.137^{* * *} \\
(-4.977)\end{array}$ & $\begin{array}{c}-0.135^{* * *} \\
(-4.898)\end{array}$ & $\begin{array}{c}-0.031^{* * *} \\
(-5.012)\end{array}$ \\
\hline $\mathrm{MOM}_{t-1}$ & & & $\begin{array}{c}0.131^{* *} \\
(2.432)\end{array}$ & & & & & $\begin{array}{c}0.126^{* *} \\
(2.353)\end{array}$ \\
\hline Reverse $_{t-1}$ & & & & $\begin{array}{l}-0.003 \\
(-0.381)\end{array}$ & & & & $\begin{array}{l}-0.003 \\
(-0.338)\end{array}$ \\
\hline Coskew $_{t-1}$ & & & & & $\begin{array}{c}-0.080^{* * * *} \\
(-9.088)\end{array}$ & & & $\begin{array}{c}-0.096^{* * *} \\
(-9.451)\end{array}$ \\
\hline Iskew $_{t-1}$ & & & & & & $\begin{array}{c}0.030^{* * *} \\
(3.275)\end{array}$ & & $\begin{array}{c}0.026^{* * *} \\
(2.819)\end{array}$ \\
\hline $\mathrm{MAX}_{t-1}$ & & & & & & & $\begin{array}{l}0.596^{*} \\
(1.684)\end{array}$ & $\begin{array}{c}-1.449^{* * *} \\
(-3.546)\end{array}$ \\
\hline Constant & $\begin{array}{c}0.196 \\
(0.743)\end{array}$ & $\begin{array}{l}-0.162 \\
(-0.615)\end{array}$ & $\begin{array}{l}-0.155 \\
(-0.589)\end{array}$ & $\begin{array}{l}-0.116 \\
(-0.439)\end{array}$ & $\begin{array}{l}-0.163 \\
(-0.622)\end{array}$ & $\begin{array}{l}-0.145 \\
(-0.550)\end{array}$ & $\begin{array}{l}-0.155 \\
(-0.590)\end{array}$ & $\begin{array}{c}0.198 \\
(0.736)\end{array}$ \\
\hline Crypt FE & Yes & Yes & Yes & Yes & Yes & Yes & Yes & Yes \\
\hline Month FE & Yes & Yes & Yes & Yes & Yes & Yes & Yes & Yes \\
\hline Observations & 9,357 & 9,357 & 9,357 & 9,357 & 9,357 & 9,357 & 9,357 & 9,357 \\
\hline Adjusted $\mathrm{R}^{2}$ & 0.037 & 0.056 & 0.057 & 0.054 & 0.065 & 0.057 & 0.056 & 0.067 \\
\hline
\end{tabular}

Table 7. Eliminate the influence of extreme samples.

\begin{tabular}{|c|c|c|c|c|c|}
\hline & \multicolumn{5}{|c|}{ Dependent variable $=\mathrm{IVOL}_{t}$} \\
\hline & (1) & $(2)$ & (3) & (4) & (5) \\
\hline Attention $_{t-1}$ & $\begin{array}{c}-0.024^{* * *} \\
(-3.236)\end{array}$ & $\begin{array}{c}-0.028^{* * *} \\
(-3.430)\end{array}$ & $\begin{array}{c}-0.052^{* * *} \\
(-4.156)\end{array}$ & $\begin{array}{c}-0.039 * * * \\
(-2.949)\end{array}$ & $\begin{array}{c}-0.016^{* *} \\
(-2.097)\end{array}$ \\
\hline Size $_{t-1}$ & $\begin{array}{c}-0.104^{* * *} \\
(-3.553)\end{array}$ & $\begin{array}{c}-0.065^{* *} \\
(-2.264)\end{array}$ & $\begin{array}{c}-0.250^{* * *} \\
(-5.929)\end{array}$ & $\begin{array}{c}-0.362^{* * *} \\
(-9.981)\end{array}$ & $\begin{array}{c}-0.014 \\
(-0.485)\end{array}$ \\
\hline Volume $_{t-1}$ & $\begin{array}{l}-0.041^{* *} \\
(-2.202)\end{array}$ & $\begin{array}{l}-0.019 \\
(-0.919)\end{array}$ & $\begin{array}{c}-0.024 \\
(-0.930)\end{array}$ & $\begin{array}{c}-0.122^{* * *} \\
(-5.201)\end{array}$ & $\begin{array}{c}-0.015 \\
(-0.661)\end{array}$ \\
\hline $\mathrm{MOM}_{t-1}$ & $\begin{array}{c}0.456 \\
(1.049)\end{array}$ & $\begin{array}{c}0.594 \\
(1.273)\end{array}$ & $\begin{array}{c}-0.498 \\
(-1.276)\end{array}$ & $\begin{array}{c}0.119^{* * *} \\
(2.599)\end{array}$ & $\begin{array}{c}0.830^{* *} \\
(2.380)\end{array}$ \\
\hline Reverse $_{t-1}$ & $\begin{array}{c}0.029 \\
(0.712)\end{array}$ & $\begin{array}{c}0.005 \\
(0.100)\end{array}$ & $\begin{array}{c}-0.048 \\
(-0.706)\end{array}$ & $\begin{array}{l}-0.002 \\
(-0.295)\end{array}$ & $\begin{array}{c}-0.041 \\
(-1.129)\end{array}$ \\
\hline Coskew $_{t-1}$ & $\begin{array}{c}-0.001 \\
(-0.049)\end{array}$ & $\begin{array}{l}-0.024 \\
(-1.189)\end{array}$ & $\begin{array}{c}-0.012 \\
(-0.701)\end{array}$ & $\begin{array}{c}-0.048^{* * *} \\
(-5.502)\end{array}$ & $\begin{array}{c}-0.035 \\
(-1.405)\end{array}$ \\
\hline Iskew $_{t-1}$ & $\begin{array}{c}0.002 \\
(0.345)\end{array}$ & $\begin{array}{c}0.000 \\
(0.037)\end{array}$ & $\begin{array}{l}0.015^{*} \\
(1.689)\end{array}$ & $\begin{array}{c}0.020^{* *} \\
(2.541)\end{array}$ & $\begin{array}{l}-0.013^{*} \\
(-1.930)\end{array}$ \\
\hline$M_{A X} X_{t-1}$ & $\begin{array}{c}5.650^{* * * *} \\
(2.800)\end{array}$ & $\begin{array}{c}10.111^{* *} \\
(2.517)\end{array}$ & $\begin{array}{c}1.683 \\
(0.649)\end{array}$ & $\begin{array}{c}-0.747^{* *} \\
(-2.141)\end{array}$ & $\begin{array}{c}46.282^{* * *} \\
(4.398)\end{array}$ \\
\hline Constant & $\begin{array}{c}0.001 \\
(0.004)\end{array}$ & $\begin{array}{c}-0.173 \\
(-1.186)\end{array}$ & $\begin{array}{c}-0.295 \\
(-1.602)\end{array}$ & $\begin{array}{c}0.342 \\
(1.417)\end{array}$ & $\begin{array}{c}0.067 \\
(0.668)\end{array}$ \\
\hline Crypt FE & Yes & Yes & Yes & Yes & Yes \\
\hline Month FE & Yes & Yes & Yes & Yes & Yes \\
\hline Observations & 4660 & 4697 & 4493 & 9286 & 2377 \\
\hline Adjusted $R^{2}$ & 0.174 & 0.133 & 0.120 & 0.096 & 0.121 \\
\hline
\end{tabular}

Notes: We take the median value of samples in the same month as the grouping standard, and exclude the small, illiquid, very young currencies and Bitcoin respectively. In this table: Model (1) delete the small market value samples; Model (2) delete the illiquid samples; Model (3) delete the young samples; Model (4) delete the samples of Bitcoin; Model (5) excludes samples with all the above characteristics. The detailed definitions of the above variables are shown in the Appendix. All continuous variables are winsorized at $1 \%$ and $99 \%$. The standard errors are clustered at the cryptocurrency level, as discussed by Petersen (2009). $t$-statistics are given in the parentheses. *, **, and *** indicate significance at the $10 \%$, $5 \%$, and $1 \%$ levels, respectively. Our sample period is from 30 April 2013 to 30 November 2020. All data are monthly. 
Table 8. The result of difference dynamic panel-data estimation.

\begin{tabular}{|c|c|c|c|}
\hline & \multicolumn{3}{|c|}{ Dependent variable $=\mathrm{IVOL}_{t}$} \\
\hline & (1) & (2) & (3) \\
\hline Attention $_{t-1}$ & $\begin{array}{c}-0.038^{* * *} \\
(-2.894)\end{array}$ & $\begin{array}{c}-0.038^{* * *} \\
(-2.894)\end{array}$ & $\begin{array}{c}-0.038^{* * *} \\
(-2.894)\end{array}$ \\
\hline Size $_{t-1}$ & $\begin{array}{c}-0.363^{* * *} \\
(-10.071)\end{array}$ & $\begin{array}{c}-0.363^{* * *} \\
(-10.071)\end{array}$ & $\begin{array}{c}-0.363^{* * *} \\
(-10.071)\end{array}$ \\
\hline Volume $_{t-1}$ & $\begin{array}{c}-0.119^{* * *} \\
(-5.088)\end{array}$ & $\begin{array}{c}-0.119^{* * *} \\
(-5.088)\end{array}$ & $\begin{array}{c}-0.119^{* * *} \\
(-5.088)\end{array}$ \\
\hline $\mathrm{MOM}_{t-1}$ & $\begin{array}{c}0.119^{* * *} \\
(2.610)\end{array}$ & $\begin{array}{c}0.119^{* * *} \\
(2.610)\end{array}$ & $\begin{array}{c}0.119^{* * *} \\
(2.610)\end{array}$ \\
\hline Reverse $_{t-1}$ & $\begin{array}{c}-0.002 \\
(-0.293)\end{array}$ & $\begin{array}{c}-0.002 \\
(-0.293)\end{array}$ & $\begin{array}{c}-0.002 \\
(-0.293)\end{array}$ \\
\hline Coskew $_{t-1}$ & $\begin{array}{c}-0.048^{* * *} \\
(-5.521)\end{array}$ & $\begin{array}{c}-0.048^{* * *} \\
(-5.521)\end{array}$ & $\begin{array}{c}-0.048^{* * *} \\
(-5.521)\end{array}$ \\
\hline Iskew $_{t-1}$ & $\begin{array}{c}0.021^{* * * *} \\
(2.602)\end{array}$ & $\begin{array}{c}0.021^{* * *} \\
(2.602)\end{array}$ & $\begin{array}{c}0.021^{* * *} \\
(2.602)\end{array}$ \\
\hline $\operatorname{MAX}_{t-1}$ & $\begin{array}{c}-0.745^{* *} \\
(-2.142)\end{array}$ & $\begin{array}{c}-0.745^{* *} \\
(-2.142)\end{array}$ & $\begin{array}{c}-0.745^{* *} \\
(-2.142)\end{array}$ \\
\hline Attention_cryptocurrency $y_{t-1}$ & $\begin{array}{c}0.009 \\
(0.138)\end{array}$ & & $\begin{array}{c}-0.008 \\
(-0.118)\end{array}$ \\
\hline Attention_digital $_{t-1}$ & & $\begin{array}{c}0.008 \\
(0.138)\end{array}$ & $\begin{array}{c}0.015 \\
(0.163)\end{array}$ \\
\hline Constant & $\begin{array}{c}0.012 \\
(0.299)\end{array}$ & $\begin{array}{c}0.006 \\
(0.103)\end{array}$ & $\begin{array}{c}0.001 \\
(0.017)\end{array}$ \\
\hline Month FE & Yes & Yes & Yes \\
\hline Crypt FE & Yes & Yes & Yes \\
\hline Observations & 9357 & 9357 & 9357 \\
\hline Adjusted $R^{2}$ & 0.095 & 0.095 & 0.095 \\
\hline
\end{tabular}

Notes: Models (1) to (3) add Attention_cryptocurrency and Attention_digital in turn. The detailed definitions of the above variables are shown in the Appendix. All continuous variables are winsorized at $1 \%$ and $99 \%$. The standard errors are clustered at the cryptocurrency level, as discussed by Petersen (2009). $t$-statistics are given in the parentheses. ${ }^{*}, * *$, and ${ }^{* * *}$ indicate significance at the $10 \%, 5 \%$, and $1 \%$ levels, respectively. Our sample period is from 30 April 2013 to 30 November 2020.All data are monthly.

market is easily affected by its past idiosyncratic risk, and the lag term of explained variables and differential GMMs can consider the impact of past factors on the current (Wintoki, Linck, and Netter 2012). According to the regression results in Table 9, after controlling the lag term of idiosyncratic risk, the regression coefficient of investor attention in all columns model are still significantly negative, which verify the robustness of our findings.

\subsection{Channel analysis: the role of liquidity}

In a previous discussion of the potential impact of investor attention on cryptocurrencies' idiosyncratic risk, we emphasize the role of liquidity in the above relationship. In this section, we attempt to justify the role of liquidity. Specifically, to explore whether investor attention decreases idiosyncratic risk through the channel of liquidity, we apply a two-step regression approach following Kim, Luo, and Xie (2016). In the first step, we examine if investor attention is associated with higher cryptocurrency liquidity $\left(\operatorname{Amihud}_{i, t}\right)$ by conducting analysis based on Equation (11). In the second step, we regress Amihud $\mathrm{i}_{\mathrm{i}, t}$ on idiosyncratic risk with the inclusion of control variables based on Equation (12).

$$
\begin{aligned}
& \text { Amihud }_{i, t}=\beta_{0}+\beta_{1} * \text { Attention }_{i, t}+\sum_{k} \gamma_{k} \operatorname{Control}_{k, i, t}+\sum \text { Cryptocurrency }_{k} \sum \text { Month }+\varepsilon_{i, t} \\
& \text { IVOL }_{i, t+1}=\beta_{0}+\beta_{1} * \text { Amihud }_{i, t}+\sum_{k} \gamma_{k} \operatorname{Control}_{k, i, t}+\sum \text { Cryptocurrency }+\sum \text { Month }+\varepsilon_{i, t+1}
\end{aligned}
$$


Table 9. The result of difference dynamic panel-data estimation.

\begin{tabular}{|c|c|c|c|c|}
\hline & \multicolumn{4}{|c|}{ Dependent variable $=\mathrm{IVOL}_{t}$} \\
\hline & (1) & $(2)$ & (3) & (4) \\
\hline Attention $_{t-1}$ & $\begin{array}{c}-0.044^{* * *} \\
(-3.285)\end{array}$ & $\begin{array}{c}-0.046^{* * *} \\
(-3.448)\end{array}$ & $\begin{array}{c}-0.046^{* * *} \\
(-3.453)\end{array}$ & $\begin{array}{l}-0.073^{*} \\
(-1.941)\end{array}$ \\
\hline Size $_{t-1}$ & $\begin{array}{c}-0.360^{* * * *} \\
(-9.873)\end{array}$ & $\begin{array}{c}-0.346^{* * *} \\
(-9.459)\end{array}$ & $\begin{array}{c}-0.349^{* * *} \\
(-9.526)\end{array}$ & $\begin{array}{c}-0.481^{* * *} \\
(-2.864)\end{array}$ \\
\hline Volume $_{t-1}$ & $\begin{array}{c}-0.112^{* * * *} \\
(-4.736)\end{array}$ & $\begin{array}{c}-0.118^{* * *} \\
(-4.961)\end{array}$ & $\begin{array}{c}-0.117^{* * *} \\
(-4.922)\end{array}$ & $\begin{array}{l}-0.061 \\
(-1.543)\end{array}$ \\
\hline $\mathrm{MOM}_{t-1}$ & $\begin{array}{c}0.121^{* * *} \\
(2.666)\end{array}$ & $\begin{array}{c}0.136^{* * *} \\
(3.020)\end{array}$ & $\begin{array}{c}0.135^{* * * *} \\
(3.004)\end{array}$ & $\begin{array}{c}0.019 \\
(0.180)\end{array}$ \\
\hline Reverse $_{t-1}$ & $\begin{array}{l}-0.003 \\
(-0.405)\end{array}$ & $\begin{array}{l}-0.001 \\
(-0.150)\end{array}$ & $\begin{array}{l}-0.001 \\
(-0.204)\end{array}$ & $\begin{array}{c}0.008 \\
(0.271)\end{array}$ \\
\hline Coskew $_{t-1}$ & $\begin{array}{c}-0.051^{* * * *} \\
(-5.864)\end{array}$ & $\begin{array}{c}-0.057^{* * *} \\
(-6.437)\end{array}$ & $\begin{array}{c}-0.057^{* * *} \\
(-6.474)\end{array}$ & $\begin{array}{c}0.004 \\
(0.105)\end{array}$ \\
\hline Iskew $_{t-1}$ & $\begin{array}{c}0.021^{* * * *} \\
(2.654)\end{array}$ & $\begin{array}{c}0.022^{* * *} \\
(2.672)\end{array}$ & $\begin{array}{c}0.022^{* * * *} \\
(2.708)\end{array}$ & $\begin{array}{l}-0.061 \\
(-1.047)\end{array}$ \\
\hline $\operatorname{MAX}_{t-1}$ & $\begin{array}{l}-0.807^{* *} \\
(-2.332)\end{array}$ & $\begin{array}{c}-0.889^{* * *} \\
(-2.582)\end{array}$ & $\begin{array}{c}-0.914 * * * \\
(-2.653)\end{array}$ & $\begin{array}{c}0.977 \\
(0.319)\end{array}$ \\
\hline $\mathrm{IVOL}_{t-1}$ & $\begin{array}{c}-0.024^{* *} \\
(-2.346)\end{array}$ & & $\begin{array}{l}-0.024^{* *} \\
(-2.291)\end{array}$ & $\begin{array}{l}-0.208^{* *} \\
(-2.435)\end{array}$ \\
\hline $\mathrm{IVOL}_{t-2}$ & & $\begin{array}{c}-0.038^{* * *} \\
(-3.648)\end{array}$ & $\begin{array}{c}-0.039^{* * *} \\
(-3.709)\end{array}$ & $\begin{array}{l}-0.011 \\
(-0.101)\end{array}$ \\
\hline Constant & $\begin{array}{l}-0.008 \\
(-0.038)\end{array}$ & $\begin{array}{l}-0.006 \\
(-0.030)\end{array}$ & $\begin{array}{l}-0.011 \\
(-0.050)\end{array}$ & $\begin{array}{c}-0.098^{* * *} \\
(-3.660)\end{array}$ \\
\hline \multirow{4}{*}{$\begin{array}{l}\text { Month FE } \\
\text { Crypt FE } \\
\text { Observations } \\
\text { Adjusted } R^{2}\end{array}$} & Yes & Yes & Yes & Yes \\
\hline & Yes & Yes & Yes & - \\
\hline & 8905 & 8,463 & 8463 & 7787 \\
\hline & 0.099 & 0.104 & 0.105 & - \\
\hline \multirow{2}{*}{$\begin{array}{l}\text { AR(1) Test ( } P \text {-value) } \\
\text { Hansen Test }\end{array}$} & 0.002 & AR(2) Test ( & & 0.246 \\
\hline & 0.189 & Difference-i & nsen Tests & 0.236 \\
\hline \multicolumn{5}{|c|}{$\begin{array}{l}\text { Notes: Models (1) to (3) add the lag term of the explained variable in turn, and Model (4) reports } \\
\text { the results of the difference dynamic panel-data estimation. Among them, AR (1) and AR (2) } \\
\text { are used to verify whether there are first-order and second-order sequence correlations in } \\
\text { GMM estimation, and Hansen test and Difference-in-Hansen Tests are used to verify whether } \\
\text { the instrumental variables in horizontal and differential forms in GMM estimation are legal. } \\
\text { The detailed definitions of the above variables are shown in the Appendix. All continuous vari- } \\
\text { ables are winsorized at } 1 \% \text { and } 99 \% \text {. The standard errors are clustered at the cryptocurrency } \\
\text { level, as discussed by Petersen (2009). } t \text {-statistics are given in the parentheses. }{ }^{*},{ }^{* *} \text {, and }{ }^{* * *} \\
\text { indicate significance at the } 10 \%, 5 \% \text {, and } 1 \% \text { levels, respectively. Our sample period is from } \\
30 \text { April } 2013 \text { to } 30 \text { November } 2020 \text {. All data are monthly. }\end{array}$} \\
\hline
\end{tabular}

where Amihud ${ }_{i, t}$ is the illiquidity level of cryptocurrency $i$ in period $t$, where the larger the value, the worse the liquidity. The definitions of other variables are in line with those in Equation (5).

Column 1 of Table 7 reports the first stage regression. We see that Attention ${ }_{i, t}$ is negatively associated with Amihud $_{i, t}$ and the result is significant at the $1 \%$ level, which suggests that increased investor attention can reduce the Amihud illiquidity level of cryptocurrencies. That is, higher the investor attention, higher the cryptocurrency liquidity is. The second step regression result is reported in Columns 2 and 3 of Table 7. The coefficient of Amihud $_{i, t}$ is positive and significant at the $1 \%$ level, which indicates that lower liquidity level exacerbates the idiosyncratic risk in the cryptocurrency markets. Specifically, liquidity is vital in the cryptocurrency market, and the market as a whole remains relatively illiquid compared to a few popular cryptocurrencies (Koutmos 2018; Dong et al. 2020). High liquidity can bring continuous transactions for cryptocurrencies, and thus promote the efficient operation of the price discovery mechanism in the market. As a result, price distortions caused by information asymmetry are greatly reduced, consequently, idiosyncratic risk is reduced. Based on the above analysis, the higher the investor attention level, the better the liquidity of cryptocurrency, lower idiosyncratic risk will follow. Overall, the above results show that liquidity arising from investor attention plays a significant role in reducing the cryptocurrency idiosyncratic risk (Table 10). 
Table 10. Channel test: The role of liquidity.

\begin{tabular}{|c|c|c|c|}
\hline \multirow[b]{2}{*}{$\underline{\text { Dependent variable }=}$} & Amihud $_{t-1}$ & $\mathrm{IVOL}_{t}$ & $\mathrm{IVOL} F F 3_{t}$ \\
\hline & (1) & $(2)$ & (3) \\
\hline Attention $_{t-1}$ & $\begin{array}{c}-0.017^{* * *} \\
(-2.894)\end{array}$ & & \\
\hline Amihud $_{t-1}$ & & $\begin{array}{l}0.467^{* * *} \\
(20.177)\end{array}$ & $\begin{array}{l}0.421^{* * *} \\
(15.327)\end{array}$ \\
\hline Size $_{t-1}$ & $\begin{array}{c}-0.910^{* * *} \\
(-65.921)\end{array}$ & $\begin{array}{l}-0.064^{*} \\
(-1.753)\end{array}$ & $\begin{array}{l}-0.065 \\
(-1.504)\end{array}$ \\
\hline Volume $_{t-1}$ & $\begin{array}{l}0.046^{* * *} \\
(14.468)\end{array}$ & $\begin{array}{c}0.007 \\
(1.033)\end{array}$ & $\begin{array}{c}0.002 \\
(0.282)\end{array}$ \\
\hline $\mathrm{MOM}_{t-1}$ & $\begin{array}{l}-0.048^{* *} \\
(-2.350)\end{array}$ & $\begin{array}{c}0.128^{* * * *} \\
(2.876)\end{array}$ & $\begin{array}{l}0.133^{* *} \\
(2.512)\end{array}$ \\
\hline Reverse $_{t-1}$ & $\begin{array}{l}-0.004 \\
(-1.188)\end{array}$ & $\begin{array}{l}-0.000 \\
(-0.028)\end{array}$ & $\begin{array}{l}-0.001 \\
(-0.133)\end{array}$ \\
\hline Coskew $_{t-1}$ & $\begin{array}{l}-0.002 \\
(-0.633)\end{array}$ & $\begin{array}{c}-0.047^{* * *} \\
(-5.548)\end{array}$ & $\begin{array}{c}-0.095^{* * * *} \\
(-9.496)\end{array}$ \\
\hline Iskew $_{t-1}$ & $\begin{array}{l}-0.003 \\
(-0.818)\end{array}$ & $\begin{array}{c}0.020^{* * *} \\
(2.630)\end{array}$ & $\begin{array}{c}0.026^{* * * *} \\
(2.829)\end{array}$ \\
\hline $\operatorname{MAX}_{t-1}$ & $\begin{array}{c}0.528^{* * * *} \\
(3.371)\end{array}$ & $\begin{array}{c}-0.978^{* * *} \\
(-2.871)\end{array}$ & $\begin{array}{c}-1.650^{* * * *} \\
(-4.084)\end{array}$ \\
\hline Constant & $\begin{array}{c}0.022 \\
(0.221)\end{array}$ & $\begin{array}{l}-0.001 \\
(-0.006)\end{array}$ & $\begin{array}{l}-0.136 \\
(-0.526)\end{array}$ \\
\hline Crypt FE & Yes & Yes & Yes \\
\hline Month FE & Yes & Yes & Yes \\
\hline $\begin{array}{l}\text { Observations } \\
\text { Adjusted } R^{2}\end{array}$ & $\begin{array}{l}9357 \\
0.586\end{array}$ & $\begin{array}{l}9357 \\
0.133\end{array}$ & $\begin{array}{l}9357 \\
0.089\end{array}$ \\
\hline \multicolumn{4}{|c|}{$\begin{array}{l}\text { Notes: This table shows the channel analyses results. Column } 1 \text { reports the effect of } \\
\text { investor attention on Amihud illiquidity, Columns } 2 \text { and } 3 \text { show the effect of Ami- } \\
\text { hud illiquidity on idiosyncratic risk. The detailed definitions of the above variables } \\
\text { are shown in the Appendix. All continuous variables are winsorized at } 1 \% \text { and } 99 \% \text {. } \\
\text { The standard errors are clustered at the cryptocurrency level, as discussed by Petersen } \\
\text { (2009). } t \text {-statistics are given in the parentheses. }{ }^{* *}, \text { and } * * * \text { indicate significance at } \\
\text { the } 10 \%, 5 \% \text {, and } 1 \% \text { levels, respectively. Our sample period is from } 30 \text { April } 2013 \text {, to } \\
30 \text { November } 2020 \text {. All data are monthly. }\end{array}$} \\
\hline
\end{tabular}

\section{Additional analysis}

Investor attention is also affected by the asymmetry of trading activities such as returns and trading volume (Takeda and Wakao 2014; Tantaopas, Padungsaksawasdi, and Treepongkaruna 2016). It is noteworthy to explore whether the impact of investor attention on cryptocurrency idiosyncratic risk varies in different situations. Therefore, we further discuss the cryptocurrency characteristics (including market value, listing age in the market, co-skewness, idiosyncratic skewness) in the investor attention and idiosyncratic risk context.

\subsection{Cryptocurrency characteristics}

In order to have a more comprehensive understanding of the relationship between investor attention and idiosyncratic risk, we examine our results under different characteristics of cryptocurrencies. Following Bushee et al. (2010), Huang, Huang, and Lin (2019) and Cheng and Yen (2020), based on the median of size and listing months in a given month, all samples are divided into the following four sub-groups: Larger-cap/Smaller-cap and Older/Younger cryptocurrencies. Then, we re-estimate the regression results based on the above sub-groups again. According to the results in Panel A of Table 11, the coefficients on investor attention in Larger-cap Group and Smaller-Group are significantly negative, while the absolute value of the former is far less than that of the latter (passing Chow-test). And it is also worth noting that the coefficient of Attention $t_{-1}$ in Younger-group is negative at the $1 \%$ significance level, while the same coefficient in Older-group is not significant. The above results indicate that investor attention has a stronger inhibitory effect on idiosyncratic risk in small market value and young cryptocurrencies. We argue that these types of cryptocurrencies are always lack of liquidity, 
Table 11. The impact of investor attention on idiosyncratic risk under different cryptocurrencies' characteristics.

\begin{tabular}{|c|c|c|c|c|}
\hline & \multicolumn{4}{|c|}{ Dependent variable $=\mathrm{IVOL}_{t}$} \\
\hline & (1) Larger-cap & (2) Smaller-cap & (3) Older & (4) Younger \\
\hline \multicolumn{5}{|l|}{ Panel A: } \\
\hline Attention $_{t-1}$ & $\begin{array}{c}-0.024^{* * *} \\
(-3.236)\end{array}$ & $\begin{array}{c}-0.087^{* * *} \\
(-2.958)\end{array}$ & $\begin{array}{c}-0.052^{* * *} \\
(-4.156)\end{array}$ & $\begin{array}{c}-0.057^{* *} \\
(-2.182)\end{array}$ \\
\hline Size $_{t-1}$ & $\begin{array}{c}-0.104^{* * *} \\
(-3.553)\end{array}$ & $\begin{array}{c}-0.604^{* * *} \\
(-8.881)\end{array}$ & $\begin{array}{c}-0.250^{* * *} \\
(-5.929)\end{array}$ & $\begin{array}{c}-0.429^{* * *} \\
(-7.147)\end{array}$ \\
\hline Volume $_{t-1}$ & $\begin{array}{c}-0.041^{* *} \\
(-2.202)\end{array}$ & $\begin{array}{c}-0.196^{* * *} \\
(-4.898)\end{array}$ & $\begin{array}{c}-0.024 \\
(-0.930)\end{array}$ & $\begin{array}{c}-0.207^{* * *} \\
(-5.288)\end{array}$ \\
\hline $\mathrm{MOM}_{t-1}$ & $\begin{array}{c}0.456 \\
(1.049)\end{array}$ & $\begin{array}{l}0.106^{*} \\
(1.679)\end{array}$ & $\begin{array}{c}-0.498 \\
(-1.276)\end{array}$ & $\begin{array}{l}0.111^{*} \\
(1.886)\end{array}$ \\
\hline Reverse $_{t-1}$ & $\begin{array}{c}0.029 \\
(0.712)\end{array}$ & $\begin{array}{c}-0.003 \\
(-0.289)\end{array}$ & $\begin{array}{c}-0.048 \\
(-0.706)\end{array}$ & $\begin{array}{c}-0.003 \\
(-0.273)\end{array}$ \\
\hline Coskew $_{t-1}$ & $\begin{array}{c}-0.001 \\
(-0.049)\end{array}$ & $\begin{array}{l}-0.025^{*} \\
(-1.731)\end{array}$ & $\begin{array}{c}-0.012 \\
(-0.701)\end{array}$ & $\begin{array}{c}-0.052^{* * *} \\
(-4.592)\end{array}$ \\
\hline Iskew $_{t-1}$ & $\begin{array}{c}0.002 \\
(0.345)\end{array}$ & $\begin{array}{c}0.015 \\
(1.057)\end{array}$ & $\begin{array}{l}0.015^{*} \\
(1.689)\end{array}$ & $\begin{array}{c}0.005 \\
(0.336)\end{array}$ \\
\hline $\mathrm{MAX}_{t-1}$ & $\begin{array}{c}5.650^{* * *} \\
(2.800)\end{array}$ & $\begin{array}{c}-0.766 \\
(-1.619)\end{array}$ & $\begin{array}{c}1.683 \\
(0.649)\end{array}$ & $\begin{array}{c}-0.888^{* *} \\
(-1.975)\end{array}$ \\
\hline Constant & $\begin{array}{c}0.001 \\
(0.004)\end{array}$ & $\begin{array}{c}0.305 \\
(0.680)\end{array}$ & $\begin{array}{c}-0.358^{* *} \\
(-2.034)\end{array}$ & $\begin{array}{c}-0.352 \\
(-0.854)\end{array}$ \\
\hline Crypt FE & Yes & Yes & Yes & Yes \\
\hline Month FE & Yes & Yes & Yes & Yes \\
\hline Observations & 4660 & 4697 & 4,493 & 4,864 \\
\hline \multirow[t]{2}{*}{ Adjusted $R^{2}$} & 0.174 & 0.105 & 0.120 & 0.111 \\
\hline & (1) Left-Coskew & (2) Right-Coskew & (3) Left-Iskew & (4) Right-Iskew \\
\hline \multicolumn{5}{|l|}{ Panel B: } \\
\hline Attention $_{t-1}$ & $\begin{array}{c}-0.016 \\
(-0.714)\end{array}$ & $\begin{array}{c}-0.044^{* * *} \\
(-2.640)\end{array}$ & $\begin{array}{c}-0.035^{* *} \\
(-2.056)\end{array}$ & $\begin{array}{c}-0.044^{* *} \\
(-2.169)\end{array}$ \\
\hline Size $_{t-1}$ & $\begin{array}{c}-0.383^{* * *} \\
(-6.341)\end{array}$ & $\begin{array}{c}-0.366^{* * *} \\
(-7.801)\end{array}$ & $\begin{array}{c}-0.250^{* * *} \\
(-4.942)\end{array}$ & $\begin{array}{c}-0.408^{* * *} \\
(-7.562)\end{array}$ \\
\hline Volume $_{t-1}$ & $\begin{array}{c}-0.167^{* * *} \\
(-4.219)\end{array}$ & $\begin{array}{c}-0.065^{* *} \\
(-2.194)\end{array}$ & $\begin{array}{c}-0.100^{* * *} \\
(-3.068)\end{array}$ & $\begin{array}{c}-0.136^{* * *} \\
(-3.908)\end{array}$ \\
\hline $\mathrm{MOM}_{t-1}$ & $\begin{array}{c}0.012 \\
(0.180)\end{array}$ & $\begin{array}{c}0.318^{* * *} \\
(4.465)\end{array}$ & $\begin{array}{l}-0.001 \\
(-0.017)\end{array}$ & $\begin{array}{c}0.150^{* *} \\
(2.518)\end{array}$ \\
\hline Reverse $_{t-1}$ & $\begin{array}{c}0.079 \\
(0.930)\end{array}$ & $\begin{array}{c}-0.002 \\
(-0.252)\end{array}$ & $\begin{array}{c}-0.085 \\
(-1.184)\end{array}$ & $\begin{array}{c}0.000 \\
(0.022)\end{array}$ \\
\hline Coskew $_{t-1}$ & $\begin{array}{c}-0.081^{* * *} \\
(-6.490)\end{array}$ & $\begin{array}{c}0.009 \\
(0.439)\end{array}$ & $\begin{array}{c}-0.062^{* *} \\
(-2.089)\end{array}$ & $\begin{array}{c}-0.044^{* * *} \\
(-4.507)\end{array}$ \\
\hline Iskew $_{t-1}$ & $\begin{array}{c}0.011 \\
(0.914)\end{array}$ & $\begin{array}{c}-0.003 \\
(-0.258)\end{array}$ & $\begin{array}{l}-0.020 \\
(-0.953)\end{array}$ & $\begin{array}{c}0.037^{* *} \\
(2.487)\end{array}$ \\
\hline MAX $_{t-1}$ & $\begin{array}{c}-1.837^{* * *} \\
(-4.447)\end{array}$ & $\begin{array}{c}15.292^{* * *} \\
(4.286)\end{array}$ & $\begin{array}{c}283.069^{* * * *} \\
(12.058)\end{array}$ & $\begin{array}{c}-0.804^{* *} \\
(-2.123)\end{array}$ \\
\hline Constant & $\begin{array}{c}-0.098 \\
(-0.325)\end{array}$ & $\begin{array}{c}0.229 \\
(0.672)\end{array}$ & $\begin{array}{c}2.723^{* * * *} \\
(7.519)\end{array}$ & $\begin{array}{c}-0.117 \\
(-0.350)\end{array}$ \\
\hline Crypt FE & Yes & Yes & Yes & Yes \\
\hline Month FE & Yes & Yes & Yes & Yes \\
\hline Observations & 3929 & 5428 & 4697 & 4660 \\
\hline Adjusted $R^{2}$ & 0.135 & 0.104 & 0.131 & 0.106 \\
\hline
\end{tabular}

Notes: We divide the full sample into the following sub-samples: Larger-cap/Smaller-cap, Older/Younger, LeftCoskew/Right-Coskew, Left-Iskew/Right-Iskew. We then rerun Equation (5) using the sub-samples respectively. The detailed definitions of the above variables are shown in the Appendix. All continuous variables are winsorized at $1 \%$ and $99 \%$. The standard errors are clustered at the cryptocurrency level, as discussed by Petersen (2009). $t$-statistics are given in the parentheses. ${ }^{*}, *$, and ${ }^{* * *}$ indicate significance at the $10 \%, 5 \%$, and $1 \%$ levels, respectively. Our sample period is from 30 April 2013, to 30 November 2020. All data are monthly.

in which the liquidity level will increase more significantly after getting higher investor attention, ultimately reduce idiosyncratic risk.

In addition, we also explore the impact of cryptocurrency return bias on investor attention and idiosyncratic risk. All samples are divided into the following four sub-groups: Left-Coskew/Right-Coskew and 
Left-Iskew/Right-Iskew. If the co-skewness and idiosyncratic skewness of a given cryptocurrency is greater than 0 , it is considered to be the Right-Coskew (Iskew) and Left-Coskew (Iskew) otherwise. Then, we re-estimate the regression results according to the above sub-groups.

According to the regression results in Panel B of Table 11, the coefficients on investor attention in RightCoskew Group and Right-Iskew Group are significantly negative, while their counter groups are insignificant. This confirms the widespread speculation in the cryptocurrency market (Baek and Elbeck 2015; Barnes 2018). When a cryptocurrency presents the characteristic of right co-skewness, it shows that the yield distribution of this cryptocurrency is obviously right biased compared with the market. Thus, the cryptocurrency may be easier to achieve extreme positive yield than the average performance of the whole market, which will cause speculators to hype and overestimate its value. Then the market forms arbitrage opportunities. Similarly, when a cryptocurrency presents the characteristic of right idiosyncratic skewness, investors prefer to choose the cryptocurrency with positive idiosyncratic skewness to obtain the opportunity of 'throw a sprat to catch a herring'.

\section{Conclusions and policy implications}

The relationship between risk and return is the core of the modern financial theory. The classic capital assets pricing model (CAPM) is based on the hypothesis of rational investors and frictionless markets. It assumes that the capital market is perfect, and investors can eliminate the idiosyncratic risk of individual assets through fully diversification. Therefore, only systematic risk would affect the equilibrium asset price whereas the idiosyncratic risk has nothing to do with the asset returns. However, relevant studies have pointed out that in the case of market friction, investors cannot hold the fully diversified portfolio. They have to bear the corresponding idiosyncratic risk, and then require the relevant risk compensation (Levy 1978; Merton 1987).

Similar to the traditional asset markets, idiosyncratic risk has also aroused enthusiastic attention in cryptocurrency markets. In this paper, the main purpose is to explore the relationship between investor attention and the idiosyncratic risk in cryptocurrency markets. We use CAPM and Fama-French three-factor model to calculate the cryptocurrency idiosyncratic risk. Then, using Google search volume as the proxy for investor attention, we find that investor attention can significantly reduce the idiosyncratic risk in the cryptocurrency markets.

Moreover, we also find that the above reduction effect of investor attention has a strong duration, that is, the current investor attention can even affect the idiosyncratic risk of the next five months. In addition, we analyze the internal transmission mechanism of attention in detail. We find that investor attention can significantly improve the liquidity of the cryptocurrency market, strengthening the continuity of transactions, and thus reduce the idiosyncratic risk. Our results verify the importance of liquidity again in the process of asset pricing.

Finally, we also analyze the heterogeneity of cryptocurrencies from individual characteristics, external market environment, and market state. We find that investor attention plays a more significant role in reducing idiosyncratic risk in cryptocurrencies with small market value and older age. In terms of external environment and market state, we find that the inhibiting effect is more obvious under the condition of low economic policy uncertainty and the up market. Overall, investor attention has a varying effect on the idiosyncratic volatility both in time and in the cross-section.

We would like to thank the workshop participants of Tianjin University Financial Engineering Research Center for valuable comments and suggestions.

\section{Disclosure statement}

No potential conflict of interest was reported by the author(s).

\section{Funding}

We acknowledge financial support from the National Natural Science Foundation of China [grant number: 72073101]. 


\section{Notes}

1. As is reposted in Ang et al. (2006), except for the idiosyncratic volatility in the U.S. between 1980 and 2003 (0.51), those values in other countries or regions such as G7 countries, Canada, France, Germany, Japan are all far less than 0.50.

2. Unlike the classical Fama-French approach, we can not use the High Minus Low (HML) factor in our analysis since most cryptocurrencies do not have a book value.

\section{Notes on contributors}

Shouyu Yao currently works as a Research Fellow at Financial Engineering Research Center, Tianjin University. He does research mainly in Financial Markets. His most recent publication is in International Review of Financial Analysis, Annals of Operations Research, Pacific-Basin Finance Journal, Accounting \& Finance, Finance Research Letters, International Review of Economics \& Finance, etc.

Xiaoran Kong currently is a $\mathrm{PhD}$ in Shandong University of Finance and Economics. She does research in International Journal of Finance and Economics, Frontiers in Environmental Science, Economic Analysis and Policy, etc.

Ahmet Sensoy received his PhD degree in Mathematics from Bilkent University in 2013. He is the recipient of the TÜBİTAK Incentive Award in 2018 and the TÜBA Young Scientist Award in 2020. He serves as an associate editor for International Review of Financial Analysis, etc.; and a guest editor for Annals of Operations Research. His work appeared in outlets such as Journal of Corporate Finance, Journal of Financial Stability, and Annals of Operations Research.

Erdinc Akyildirim obtained his $\mathrm{PhD}$ in Banking and Finance from the University of Zurich. He is a senior associate scientist at the Department of Banking and Finance, University of Zurich. His research interests include applications of Stochastic Optimal Control in Economics and Finance and Machine Learning applications in finance. His works have appeared in outlets such as Journal of Corporate Finance, Journal of Mathematical Economics, Quantitative Finance, Annals of Applied Probability, Annals of Operations Research.

Feiyang Cheng currently is a $\mathrm{PhD}$ in Tianjin University. He does research in Corporate Finance, Behavioral Finance, and Business Ethics. His most recent publications are in International Review of Financial Analysis, Pacific-Basin Finance Journal, Accounting \& Finance, Finance Research Letters, Economic Modelling, Economic Analysis and Policy, etc.

\section{ORCID}

Ahmet Sensoy (D) http://orcid.org/0000-0001-7967-5171

Feiyang Cheng (D) http://orcid.org/0000-0001-9344-1582

\section{References}

Aalborg, H. A., P. Molnár, and J. E. Vries. 2019. "What Can Explain the Price, Volatility and Trading Volume of Bitcoin?." Finance Research 29: 255-265.

Amihud, Y. 2002. "Illiquidity and Stock Returns: Cross-Section and Time-Series Effects." Journal of Financial Markets 5 (1): 31-56. Andrei, D., and M. Hasler. 2015. "Investor Attention and Stock Market Volatility." Review of Financial Studies 28 (1): 33-72.

Ang, A., R. J. Hodrick, Y. Xing, and X. Zhang. 2006. “The Cross-Section of Volatility and Expected Returns.” Journal of Finance 61 (1): 259-299.

Baek, C., and M. Elbeck. 2015. "Bitcoins as an Investment or Speculative Vehicle? A First Look." Applied Economics Letters 22 (1): 30-34.

Bali, T. G., and N. Cakici. 2008. "Idiosyncratic Volatility and the Cross Section of Expected Returns." Journal of Financial and Quantitative Analysis 43 (1): 29-58.

Barber, B. M., and T. Odean. 2008. "All That Glitters: The Effect of Attention and News on the Buying Behavior of Individual and Institutional Investors." Review of Financial Studies 21 (2): 785-818.

Barnes, P. 2018. "Crypto Currency and its Susceptibility to Speculative Bubbles, Manipulation, Scams and Fraud." Journal of Advanced Studies in Finance (JASF) 9 (2 (18)): 60-77.

Baur, D. G., and T. Dimpfl. 2018. "Asymmetric Volatility in Cryptocurrencies." Economics Letters 173: 148-151.

Borri, N. 2019. "Conditional Tail-Risk in Cryptocurrency Markets." Journal of Empirical Finance 50: 1-19.

Bushee, B. J., J. E. Core, W. Guay, and S. J. W. Hamm. 2010. “The Role of the Business Press as an Information Intermediary.” Journal of Accounting Research 48: 1-19.

Bystrom, H., and D. Krygier. 2018. What Drives Bitcoin Volatility? Available at SSRN 3223368.

Cao, C., T. Simin, and J. Zhao. 2008. "Can Growth Options Explain the Trend in Idiosyncratic Risk?" Review of Financial Studies 21 (6): 2599-2633.

Cheng, F., C. Chiao, C. Wang, Z. Fang, and S. Yao. 2020. "Does Retail Investor Attention Improve Stock Liquidity? A Dynamic Perspective." Economic Modelling 94: 170-183. 
Cheng, H. P., and K. C. Yen. 2020. “The Relationship Between the Economic Policy Uncertainty and the Cryptocurrency Market." Finance Research Letters 35: 101308.

Choi, S. Y. 2020. "Industry Volatility and Economic Uncertainty due to the COVID-19 Pandemic: Evidence from Wavelet Coherence Analysis.” Finance Research Letters 37: 101783.

Da, Z., J. Engelberg, and P. Gao. 2011. “In Search of Attention.” Journal of Finance 66 (5): 1461-1499.

Dastgir, S., E. Demir, G. Downing, G. Gozgor, and C. K. M. Lau. 2019. “The Causal Relationship Between Bitcoin Attention and Bitcoin Returns: Evidence from the Copula-Based Granger Causality Test.” Finance Research Letters 28: 160-164.

DellaVigna, S., and J. M. Pollet. 2009. “Investor Inattention and Friday Earnings Announcements." Journal of Finance 64 (2): 709-749.

Ding, R., and W. Hou. 2015. "Retail Investor Attention and Stock Liquidity. Journal of International Financial Markets.” Institutions and Money 37: 12-26.

Dong, B., L. Jiang, J. Liu, and Y. Zhu. 2020. Liquidity in Cryptocurrency Market and Commonalities Across Anomalies. Available at SSRN 3563952.

Fama, E. F., and K. R. French. 1993. “Common Risk Factors in the Returns on Stock and Bonds.” Journal of Financial Economics 33 (1): 3-56.

Fang, T., Z. Su, and L. Yin. 2020. "Economic Fundamentals or Investor Perceptions? The Role of Uncertainty in Predicting LongTerm Cryptocurrency Volatility.” International Review of Financial Analysis 71: 101566.

Figa-Talamanca, G., and M. Patacca. 2019. “Does Market Attention Affect Bitcoin Returns and Volatility?” Decisions in Economics and Finance 42 (1): 135-155.

Fu, F. 2009. "Idiosyncratic Risk and the Cross-Section of Expected Stock Returns." Journal of Financial Economics 91 (1): 24-37.

Garcia, D., C. J. Tessone, P. Mavrodiev, and N. Perony. 2014. "The Digital Traces of Bubbles: Feedback Cycles Between SocioEconomic Signals in the Bitcoin Economy." Journal of the Royal Society Interface 11 (99): 20140623.

Grobys, K., and J. P. Junttila. 2020. Speculation and Lottery-Like Demand in Cryptocurrency Markets. Available at SSRN 3551948.

Harvey, C. R., and A. Siddique. 2000. “Time-Varying Conditional Skewness and the Market Risk Premium.” Research in Banking and Finance 1 (1): 27-60.

Hirshleifer, D., S. H. Teoh, and J. J. Yu. 2011. “Short Arbitrage, Return Asymmetry, and the Accrual Anomaly.” Review of Financial Studies 24 (7): 2429-2461.

Huang, S. Y., Y. L. Huang, and T. C. Lin. 2019. “Attention Allocation and Return co-Movement: Evidence from Repeated Natural Experiments.” Journal of Financial Economics 132: 369-383.

Ibikunle, G., F. McGroarty, and K. Rzayev. 2020. "More Heat Than Light: Investor Attention and Bitcoin Price Discovery." International Review of Financial Analysis 69: 101459.

Jiang, G. J., D. Xu, and T. Yao. 2009. “The Information Content of Idiosyncratic Volatility.” Journal of Financial and Quantitative Analysis 44 (1): 1-28.

Kahneman, D., and A. Tversky. 1973. "On the Psychology of Prediction.” Psychological Review 80 (4): 237.

Kang, N., P. Kondor, and R. Sadka. 2014. “Do Hedge Funds Reduce Idiosyncratic Risk?” Journal of Financial and Quantitative Analysis 49: 843-877.

Katsiampa, P. 2017. "Volatility Estimation for Bitcoin: A Comparison of GARCH Models.” Economics Letters 158: 3-6.

Katsiampa, P. 2019. “An Empirical Investigation of Volatility Dynamics in the Cryptocurrency Market.” Research in International Business and Finance 50: 322-335.

Kim, J. B., L. Luo, and H. Xie. 2016. Dividend Payments and Stock Price Crash Risk. Working Paper.

Koutmos, D. 2018. “Liquidity Uncertainty and Bitcoin's Market Microstructure.” Economics Letters 172: 97-101.

Kristoufek, L. 2013. "Bitcoin Meets Google Trends and Wikipedia: Quantifying the Relationship Between Phenomena of the Internet era." Scientific Reports 3 (1): 1-7.

Lammer, D., T. Hanspal, and A. Hackethal. 2019. Who are the Bitcoin Investors? Evidence from Indirect Cryptocurrency Investments. Working Paper.

Levy, H. 1978. "Equilibrium in an Imperfect Market: A Constraint on the Number of Securities in the Portfolio." American Economic Review 68 (4): 643-658.

Li, X., J. A. Hendler, and J. L. Teall. 2016. “Investor Attention on the Social web.” Journal of Behavioral Finance 17 (1): $45-59$.

Liu, W., X. Liang, and G. Cui. 2020. “Common Risk Factors in the Returns on Cryptocurrencies.” Economic Modelling 86: $299-305$.

Liu, Y., and A. Tsyvinski. 2018. Risks and Returns of Cryptocurrency. Available at SSRN 3226952.

Liu, Y., A. Tsyvinski, and X. Wu. 2019. "Common Risk Factors in Cryptocurrency." (No. w25882). National Bureau of Economic Research.

Loi, H. 2018. "The Liquidity of Bitcoin.” International Journal of Economics and Finance 10 (1): 13-22.

Long, H., A. Zaremba, E. Demir, J. J. Szczygielski, and M. Vasenin. 2020. "Seasonality in the Cross-Section of Cryptocurrency Returns." Finance Research Letters 35: 101566.

Merton, R. 1987. “A Simple Model of Capital Market Equilibrium with Incomplete Information.” Journal of Finance 42 (3): $483-510$.

Petersen, M. A. 2009. "Estimating Standard Errors in Finance Panel Data Sets: Comparing Approaches.” Review of Financial Studies 22 (1): 435-480.

Scharnowski, S. 2020. "Understanding Bitcoin Liquidity.” Finance Research Letters 38: 101477.

Shen, D., A. Urquhart, and P. Wang. 2019. “Does Twitter Predict Bitcoin?” Economics Letters 174: 118-122. 
Smales, L. A. 2020. "One Cryptocurrency to Explain Them all? Understanding the Importance of Bitcoin in Cryptocurrency Returns.” Economic Papers 39: 118-132.

Subramaniam, S., and M. Chakraborty. 2020. "Investor Attention and Cryptocurrency Returns: Evidence from Quantile Causality Approach." Journal of Behavioral Finance 21 (1): 103-115.

Takeda, F., and T. Wakao. 2014. "Google Search Intensity and its Relationship with Returns and Trading Volume of Japanese Stocks." Pacific-Basin Finance Journal 27: 1-18.

Tantaopas, P., C. Padungsaksawasdi, and S. Treepongkaruna. 2016. “Attention Effect via Internet Search Intensity in Asia-Pacific Stock Markets." Pacific-Basin Finance Journal 38: 107-124.

Tinic, M., A. Sensoy, E. Akyildirim, and S. Corbet. 2020. Adverse Selection in Cryptocurrency Markets. Working Paper.

Tiwari, A. K., R. K. Jana, D. Das, and D. Roubaud. 2018. "Informational Efficiency of Bitcoin-An Extension.” Economics Letters 163: 106-109.

Urquhart, A. 2016. “The Inefficiency of Bitcoin.” Economics Letters 148: 80-82.

Urquhart, A. 2017. The Volatility of Bitcoin. Available at SSRN 2921082.

Urquhart, A. 2018. "What Causes the Attention of Bitcoin?" Economics Letters 166: 40-44.

Vozlyublennaia, N. 2014. "Investor Attention, Index Performance, and Return Predictability." Journal of Banking \& Finance 41: 17-35.

Walther, T., T. Klein, and E. Bouri. 2019. "Exogenous Drivers of Bitcoin and Cryptocurrency Volatility-A Mixed Data Sampling Approach to Forecasting." Journal of International Financial Markets Institutions and Money 63: 101133.

Wei, W. C. 2018. "Liquidity and Market Efficiency in Cryptocurrencies." Economics Letters 168: 21-24.

Wintoki, M. B., J. S. Linck, and J. M. Netter. 2012. "Endogeneity and the Dynamics of Internal Corporate Governance.” Journal of Financial Economics 105 (3): 581-606.

Yao, S., C. Wang, X. Cui, and Z. Fang. 2019. "Idiosyncratic Skewness, Gambling Preference, and Cross-Section of Stock Returns: Evidence from China." Pacific-Basin Finance Journal 53: 464-483.

Yi, S., Z. Xu, and G. J. Wang. 2018. "Volatility Connectedness in the Cryptocurrency Market: Is Bitcoin a Dominant Cryptocurrency?” International Review of Financial Analysis 60: 98-114.

Yuan, Y. 2015. “Market-wide Attention, Trading, and Stock Returns.” Journal of Financial Economics 116 (3): $548-564$.

Zhang, W., and Y. Li. 2020. "Is Idiosyncratic Volatility Priced in Cryptocurrency Markets?" Research in International Business and Finance 101252.

Zhang, W., and P. Wang. 2020. "Investor Attention and the Pricing of Cryptocurrency Market." Evolutionary and Institutional Economics Review 17 (2): 445-468. 